\title{
Immunological and Molecular Mechanisms Leading to Fibrosis: Origin of Renal Myofibroblasts
}

\author{
Leonóra Himer ${ }^{1}$, Erna Sziksz¹, Tivadar Tulassay ${ }^{1,2}$ and Ádám Vannay ${ }^{1}$ \\ ${ }^{1}$ Research Group for Paediatrics and Nephrology, Semmelweis University and \\ Hungarian Academy of Sciences, Budapest, \\ ${ }^{2}$ First Department of Paediatrics, Semmelweis University, Budapest \\ Hungary
}

\section{Introduction}

There are about quarter of million patients on chronic renal replacement therapy in Europe, and the estimated number of patients with chronic kidney disease, stages 1-4 is about tenfold higher. Interestingly, regardless of the initiating cause (infection, autoimmune response, chemical insult, radiation or tissue injury etc.), the mechanism of fibrosis is similar in the different chronic kidney diseases and characterized by inflammation. In general, the damaged glomerular or tubular cells release danger signals (Anders, 2010; McDonald et al., 2010) and produce chemotactic stimuli, which trigger the rapid recruitment of leukocytes. The infiltrating immune and the damaged renal cells then produce high levels of proinflammatory cytokines, growth factors, chemokines and adhesion molecules which contribute to glomerular/tubular injury, accumulation of further leukocytes and myofibroblasts, which are the effector cells of renal fibrosis. However the origin of the myofibroblasts is still controversial recent hypotheses suggest that myofibroblasts can originate from different renal cells, such as epithelial and endothelial cells, pericytes or the bone marrow derived fibrocytes. The thus generated myofibroblasts then serves as the key cellular mediator of renal fibrosis. Myofibroblasts have migratory capacity, are resistant to apoptosis, produce several growth factors and cytokines and according to our present knowledge these cells are the main source of the collagen-I and collagen-III rich extracellular matrix in the fibrous tissue. Organ fibrosis is characterized by excessive deposit of extracellular matrix (ECM) leading to glomerular sclerosis and renal tubule-interstitium fibrosis. The excessive deposition of fibrous tissue replaces healthy kidney tissue; the nephrons disappear and the kidney function gradually declines. In this chapter we will summarize our knowledge about the role of immune cells and molecular changes leading to generation of renal myofibroblasts.

\section{Role of immune system}

Progressive renal diseases always have an inflammatory component, characterized by the infiltration of different leukocytes, overexpression of inflammatory genes and release of pro- 
inflammatory cytokines. In the following paragraphs we will summarise the role of the different immune cells in the pathomechanism of renal fibrosis.

\subsection{Neutrophil granulocytes}

Neutrophil granulocytes are polymorphonuclear cells, which constitute the majority of circulating leukocytes and respond quickly to chemotactic stimuli. They are the first immune cells, which migrate to the inflamed tissue and eliminate the pathogens and tissue debris by enzymatic degradation or by reactive oxygen species; moreover, they attract and activate further immune cells by producing different chemokines and cytokines. These cells are generally regarded as short-lived and terminally differentiated leukocytes. Kidney injury leads to the rapid influx of neutrophils and subsequent monocyte and other leukocyte recruitment (Machida et al., 2010). Damaged renal cells produce different cytokines and chemokines (e.g.: interleukin (IL)-8 (Hang et al., 2000; Topley et al., 2005), IL-17 (Kitching et al., 2011) macrophage inflammatory protein (MIP)-1, monocyte chemoattractant protein (MCP)-1 (Li et al., 2005)) which - among other leukocytes - efficiently attract neutrophils. Neutrophils become activated by immune complexes became trapped in the glomerulus or through pattern recognition receptors by damage associated or pathogen-associated molecular patterns (DAMP/PAMP) signals (like macrophages, see in details later). In response to specific stimuli, neutrophils have the capacity to synthesize several factors such as extracellular matrix and antimicrobial proteins (defensins), reactive oxygen species, cytokines (IL-1- $\beta$, tumor necrosis factor (TNF)- $\alpha$ ) and chemokines (IL-8, MIPs) that can contribute in regulating the inflammatory response (Cassatella, 1999; Sawyer et al., 1989; Fantone \& Ward, 1985). Neutrophils are able to generate arachidonic acid-derived lipid mediators, such as leukotriene B4, which is also a potent chemoattractant for leukocytes (Busse, 1998). Neutrophils have been shown to generate prostaglandin E2 and tromboxane via the inducible cyclooxigenase 2 pathway (Maloney et al, 1998). Prostaglandine E2 has both pro-and anti-inflammatory properties, for example it regulates vascular permeability, so contribute the accumulation of immune cells to the target tissue. Many of these cytokine-, lipid- and oxygen-derived mediators are regulated by nuclear factor (NF)- $\kappa \mathrm{B}$ activation, which supports neutrophils in direct pathogen killing (Blackwell et al., 1997). Although these important host defense functions, neutrophils also have an destructive capacity and can elicit significant tissue damage. For example, in antineutrophil cytoplasmic antibody associated diseases immune complexes became trapped on the endothelial surface in the vasculature of glomerulus, and the local activation of neutrophils and monocytes may disrupt the integrity of tissue architecture (Weidner et al., 2004). Human polymorphonuclear cells may be activated by particulate uromodulin (also known as: Tamm-Horsfall glycoprotein), which is the most abundant protein excreted in the urine under physiological conditions, but its biological function is still not fully understood (Rampoldi et al., 2011). Neutrophil-uromodulin interaction in the renal interstitium is characterized by the activation of the respiratory burst, as well as by comprehensive polymorphonuclear cell degranulations, which lead to marked tissue damage and eventually result in interstitial fibrosis (Horton et al., 1990). Ichino et al has been detected a marked upregulation of neutrophil-gelatinase associated lipocalin at the mRNA and protein levels in a rat model of renal scarring. This molecule has been proposed over the past years as emergent biomarkers for the early and accurate diagnosis and monitoring of acute kidney injury (Ichino et al., 2010). After they completed their role in the damaged kidney, 
neutrophils undergo apoptotic cell death. The phagocytic uptake of apoptotic neutrophils (and other cells) and other anti-inflammatory signals favor macrophage polarization toward anti-inflammatory (M2c) or profibrotic (M2a) M2 phenotypes (Swaminathan \& Griffin, 2008). Furthermore, tumor-conditioned granulocytes may play a role in priming macrophages toward either an M1 or M2 phenotype (Tsuda et al., 2004).

\subsection{Monocytes and macrophages}

Cells of monocyte/macrophage lineage are always present and are the predominant infiltrating cell type both in experimental models and in human chronic kidney diseases (CKDs). Macrophages produce a wide variety of different cytokines, chemokines and growth factors, reactive oxygen and nitrogen species, matrix metalloproteinases and component of the extracellular matrix. Thus, the presence of macrophages often correlates with the degree of fibrosis, so infiltrated macrophages has been considered to be key effector cells by modulating inflammatory response and subsequent proliferation of myofibroblasts, extracellular matrix deposition and other fibrotic processes (Eddy, 1995). However, a significant number of reports noted an inverse correlation between the number of interstitial macrophages and the degree of fibrosis, especially at the later stage of the CKD. Therefore macrophages are also assumed to have a role in the repair processes of the injured kidney (Kushiyama et al., 2010; Cochrane et al., 2005). How is it possible that macrophages have functions, which are so different from each other? Recent works indicates that recruited monocytes may differentiate into at least two different types of tissue macrophages (Anders \& Riu, 2011). Renal infection (bacterial or fungal cell wall components, viruses), degraded ECM or cell necrosis induces the differentiation of proinflammatory, "classically activated" M1 macrophages that may exacerbate renal cell damage. In contrast, uptake of apoptotic cells induces "alternatively activated" M2 macrophages, which have anti-inflammatory (M2c/suppressor), profibrotic (M2a/wound healing) or fibrolytic (M2b) properties (Gordon \& Taylor, 2005; Mosser \& Edwards, 2008; Mantovani et al., 2004). In renal fibrosis, classically and alternatively activated macrophage functions are not always sharply separated from each other, since some factors are required in the development and functions of both types.

\subsubsection{Classically activated 'M1' macrophages}

Tissue injury triggers a rapid influx of neutrophils that is followed by an increased adhesion of circulating monocytes to the activated endothelial surfaces and their subsequent extravasation into the renal interstitium (Muller, 2009). In obstructive nephropathy, flow cytometric analysis revealed a marked increase in cell counts of macrophages in the obstructed kidney. The depletion of Mac-1/CD11b+ monocyte lineages including macrophages and dendritic cells attenuated renal fibrosis, thus suggesting the importance of monocyte lineage in the development of the early phase of renal fibrotic diseases (Machida et al., 2010). Duffield et al. also showed that macrophage depletion reduced the number of interstitial myofibroblasts and CD4+ T lymhocytes, and attenuated the degree of fibrosis in the diseased kidney (Duffield et al., 2005). Renal epithelial, capillary endothelial cells and infiltrated leukocytes produce various chemokines, which are responsible for the early recruitment of macrophages into the injured tissue (Crisman et al., 2001). For example the levels of CC chemokines (MCP-1/CCL-2, macrophage inhibitory protein (MIP)-1 $\alpha$ /CCL-3, "regulated on activation normal T cell expressed and secreted" (RANTES/CCL-5)) are 
quickly increased after unilateral ureteral obstruction (UUO) (Vielhauer et al., 2001). Targeted deletion or blockade of these chemokines (Wada et al., 2004; Li et al., 2005) or chemokine receptors (Kitagawa et al., 2004; Eis et al., 2004) primarily interrupted the initial phase of macrophage infiltration and resulted in reduced inflammation and subsequent renal fibrosis. Also at the early stage of inflammation, DAMP (such as ATP, uric acid, hypomethylated DNA) or PAMP (such as bacterial lipopolysaccharide), lipoteichoic acid, peptidoglycan, double-stranded RNA, unmethylated CpG motifs) activate Toll-like (TLR) and other pattern recognition receptors of leukocytes and inherent renal cells. TLR activation on the monocytes and the presence of interferon (IFN)- $\gamma$ are essential for the expression of interferon-related factor 5 . It is required for the complete activation of NF- $\mathrm{KB}$ signaling and thus for the maturation of the proinflammatory M1 macrophage phenotype (Krausgruber et al., 2011). However, after the early inflammation response, in the progressive fibrotic stage macrophage activation may occur in TLR-independent pathways as well (Chowdhury et al., 2010). In addition, in the most types of glomerulonephritis, immune complexes can deposit in the glomerulus and bind leukocyte receptors including activating immunoglobulin Fc receptors and complement receptors to activate macrophages with similar activation and cytokine release pattern that described for DAMP/PAMP signals (Ravetch et al., 2001). The mature proinflammatory M1 macrophages then release matrix-metalloproteases (MMPs), which may induce the destruction of vascular and tubular basement membranes and further migration of inflammatory and fibrotic cells into the interstitial space (Song et al., 2000; Gibbs et al., 1999). MMPs also promote the degradation of ECM that results small ECM fragments, which can serve as immunstimulatory DAMP signals to maintain M1 macrophage phenotype (Sorokin, 2004). Stimulation of the production of MMPs by M1 macrophages during the later stages of fibrosis may shift the equilibrium towards ECM degradation and play an important anti-fibrotic role (see below). In M1 macrophages NF- $\mathrm{KB}$ is activated early after renal damage and controls the expression of multiple proinflammatory factors, such as chemokines (to recruit additional immune cells), adhesion molecules (to help the leukocyte adhesion and extravasation into the tissue), proinflammatory cytokines (to activate tissue or accumulated immune cells), lipid mediators and reactive oxygen species that support neutrophils in direct pathogen killing (Blackwell \& Christman 1997). Furthermore, in M1 macrophages the synthesis of inducible nitric oxide synthase is also triggered by NF- $\kappa B$ proinflammatory pathway (Musial \& Eissa, 2001). Nitric oxide (NO) produced by inducible nitric oxide synthase has a well known protective function against renal fibrosis (Hochberg et al., 2000; Morrissey et al., 1996). M1 macrophages express Major Histocompatibility Complex (MHC) class II molecules on their cell surface, so have antigen-presenting capacity to activate naive $\mathrm{T}$ cells by antigen-specific manner. In this process macrophage IL-12 and IL-18 as a cofactor play an important role, because they promote the generation of $\mathrm{T}$ helper (Th) 1 cell phenotype and potentially maintenance of proinflammatory Th1 responses (Kitching et al., 2005). M1 macrophages produce one of the most important proinflammatory cytokine IL-6, which have a significant role in releasing acute phase proteins from the liver, which is an early sign of inflammation. Elevated levels of the acute phase C-reactive protein may promote early renal inflammation and fibrosis by the activation of both proinflammatory NF- $\mathrm{kB}$ and profibrotic transforming growth factor (TGF)- $\beta$ /Smad signaling pathways (Li et al., 2011). Following renal damage, renal epithelial cells, denditic cells and M1 macrophages release large amount of TNF- $\alpha$, which has a paracrine/autocrine effect on macrophage activation. TNF- $\alpha$ mediates 
proapoptotic effects to limit the survival of activated immune cells (Wajant et al., 2003), but also induces activation and apoptosis of renal mesangial cells (Misseri et al., 2005; Duffield et al., 2000). NF- $\kappa B$ regulates the expression of TNF- $\alpha$, which in turn may activate NF- $\kappa B$ (Ozes et al., 1999). Like TNF- $\alpha$, after renal injury IL-1 cytokine levels are also upregulated. IL-1 may contribute to the development of renal interstitial injury and fibrosis, because IL-1 receptor blockade decreases the number of infiltrated macrophages and alpha smooth muscle actin ( $\alpha$-SMA)+ myofibroblasts (Yamagishi et al., 2001).

\subsubsection{Alternatively activated 'M2' macrophages}

Apoptotic cells of the injured kidney are rapidly recognized and phagocytosed by macrophages. This process effectively promotes their differentiation into alternatively activated M2 macrophages (Ricardo et al., 2008; Fadok et al., 1998). M2 macrophages express typically high-level of scavenger and mannose receptors, which may promote macrophage activation and phagocytosis by a TLR-independent manner. Besides the phagocytosis of apoptotic cells, the induction of M2 macrophages requires other anti-inflammatory signals favor macrophage polarization, like Th2 or regulatory $\mathrm{T}$ (Treg) cytokines and other antiinflammatory agents such as corticosteroids (Goerdt \& Orfanos, 1999). Like M1 macrophages, M2 macrophages are also characterized by expression of MHC class II molecules, and have antigen-presenting capacity to activate naive T cells towards Th2 or Treg phenotype (Gordon, 2003). The phagocytosis of the apoptotic cells that generated during the early immune response especially promotes the differentiation of antiinflammatory M2c/supressor phenotype (Swaminathan \& Griffin, 2008). Regulatory T cells via release of IL-10 and TGF- $\beta$ are also required to the polarization of macrophages towards type M2c. M2c macrophages attenuate organ injury by downregulating inflammation, predominantly the Th1 response (Herbert et al., 2004). They secrete anti-inflammatory mediators, such as IL-10, TGF- $\beta$ and other immune suppressive factors (Mosser \& Edwards, 2008). Furthermore, M2c macrophages play a positive role in epithelial (tubular reepithelization) and vascular (angiogenesis) repair and tissue remodeling. Insufficient tissue repair lead to increased secretion of different profibrotic cytokines and growth factors such as TGF- $\beta$ (Kaneto et al., 1993) or platelet derived growth factor receptor (PDGF) (Fellström et al., 1989), which promote the differentiation of macrophages into M2a/wound healing macrophages that accelerate fibrogenesis (Gurtner et al., 2008). This process is supported by Th2 cells that release IL- 4 and IL-13 cytokines, which further promote the polarization of M2a macrophage phenotype (Mantovani et al., 2004). M2a macrophages preferentially express the macrophage scavenger receptor (CD204), the mannose receptor (CD206) and fibronectin-1 which provide signals for tissue repair and proliferation. M2a macrophages are characterized by the generation of arginase-1, which may enhance collagen biosynthesis by supressing proinflammatory NO production (Bronte \& Zanovello, 2005). Interestingly organ fibrosis may be reversible. Recently the role of fibrolytic M2b macrophages was demonstrated in this process. Actually M2b macrophages have the potential to limit or reverse fibrogenesis by the secretion of different matrix metalloproteinases (Ronco \& Chatziantoniou, 2008). MMPs have a digestive capacity against ECM proteins (especially against collagen IV and denatured collagen I) without concomitant secretion of proinflammatory cytokines. Indeed MMPs have dual role in renal inflammation and fibrosis (Zeisberg et al., 2006). During UUO the expression of tissue inhibitor of 
metalloproteinases-1 (TIMP-1) and -2 (TIMP-2), which are the main regulators of MMP synthesis can vary. Increased TIMP activity during the early phase of renal fibrosis lead to the decreased expression of MMP-2 and MMP-9 in the obstructed kidneys, which inhibits the degradation of ECM components. However, TIMP expression is attenuated in the chronic stage of UUO, which allows MMP synthesis by fibrolytic macrophages and ECM degradation, so collagen levels may return to control values (Sharma et al., 1995; Kim et al., 2001). Recent studies demonstrated that the early inhibition of MMP-2 activity ameliorates renal fibrosis, but MMP-2 inhibition during the late phase of fibrosis may results in more severe disease progression (Nishida et al., 2007; Lutz et al., 2005).

\subsection{Dendritic cells}

Dendritic cells (DCs) are antigen-presenting innate immune cells, which belong to the mononuclear phagocyte system and fulfill a sentinel function. In the obstructed kidney, flow cytometric analysis showed- beside other leukocytes - increased number of F4/80+ macrophages and dendritic cells (Machida et al., 2010). Kitamoto et al. demonstrated in the early stage of UUO, that either F4/80+ monocytes/macrophages, F4/80+ dendritic cells, or both cell types contribute to the development of renal fibrosis and tubular apoptosis (Kitamoto et al., 2009). Other studies found that DC accumulation in the interstitium is associated with the loss of renal function and the progression of tubulointerstitial fibrosis (Wu et al., 2006; Zhou et al., 2009). According to their typical antigen and chemokine expression and the tendency to migrate toward inflamed tissue DCs are differentiated either myeloid (mDC) or plasmacytoid phenotype (pDC). Myeloid DCs are characterized by the expression of CD11c/blood dendritic cell antigen 1, while the specific marker of plasmacytoid DCs is the CD11c/ blood dendritic cell antigen 2. Verkade et al. showed an impaired terminal differentiation of mDCs in patients with severe chronic kidney disease (Verkade et al., 2007). Tucci et al found that the number of peripheral pDCs is correlated with the degree of lupus nephritis, whereas mDCs were almost absent in the glomeruli. In this disease only IL-18R+ pDCs were susceptible to increased expression of IL-18 and relocate within the glomeruli, where they triggers the resident $\mathrm{T}$ cells, thus promoting renal damage (Tucci et al., 2008, 2009). Infiltrated DCs become activated through pattern recognition receptors by DAMP/PAMP signals or by immune complexes via Fc receptors or complement receptors. These dendritic cells are the early source of the proinflammatory mediators after acute kidney injury and play a specific role in recruitment and activation of effector/memory $\mathrm{T}$ cells. The capacity of macrophages and dendritic cells to present antigens on MHC molecules and additionally produce IL-12/IL-23 or IL-10 strongly influences the outcome of the Th1/Th17 or Th2 T cell response (Langenkamp et al., 2000; Dong et al., 2008; Liu et al, 1998). Dendritic cell-specific intercellular adhesion molecule 3grabbing nonintegrin (DC-SIGN) is a marker of dendritic cells, which is important for DC in migrating, recognizing, antigen presenting and in initiating $\mathrm{T}$ cell responses. In a nephritis model, the expression of DC-SIGN, which was mainly expressed on tubular epithelial cells and DCs correlated with the degree of fibrosis, and was elevated by TNF- $\alpha$ treatment. These results suggest that DC-SIGN plays an important role in renal fibrosis by DC-mediated immuno-inflammatory responses (Zhou et al., 2009). Angiotensin II (Ang II) mediates proinflammatory effect also in the relationship of DCs, because AngII blockade with the Ang II receptor antagonist valsartan inhibited the local accumulation of dendritic cells and 
attenuated renal tubulointerstitial damage in rat fibrotic renal tissue (Wu et al, 2006). Muller et al demonstrated by using human renin and angiotensinogen double-transgenic rats, that Ang II induces DC migration directly, whereas in vivo TNF- $\alpha$ is involved in DC infiltration and maturation (Muller et al., 2002).

\subsection{Mast cells}

Mast cells (MCs) are known to participate in the pathogenesis of tubulointerstitial fibrosis in the different kidney diseases (Colvin et al., 1974; Pavone-Macaluso, 1960). MCs are present in every vascularized tissue, including the kidney (Kitamura, 1989). The localization of MCs is mainly interstitial, or in smaller extent periglomerular, but they have were never found in the glomeruli (Ehara \& Shigematsu, 1998; Hiromura et al., 1998). MCs can be identified by their specific granular proteoglycans content by staining with metachromatic dyes or by using immunohistochemical staining with anti-tryptase and anti-chymase antibodies. In general, three MC subtypes are present in the kidney: the tryptase-positive mucosal type, the double-positive tryptase-chymase connective tissue type, and the third chymasepositive type MCs. The ratio of the different subtypes of MCs (in the renal interstitium can differ in the various renal diseases (Beil et al., 1998). There are certain factors, which can promote the recruitment of MCs into the damaged kidney. Perhaps the most well known is the stem cell factor, which is known as the prototypic growth factor for MCs. Stem cell factor is produced mainly by tubular epithelial cells and by infiltrating interstitial leukocytes (ElKoraie et al., 2001). TGF- $\beta$ also has been described as a powerful chemoattractant for MCs (Gruber et al., 1994). In addition to these factors, IL-9, a Th2 cytokine, may enhance survival and proliferation of MCs (Godfraind et al., 1998). The activation of mast cells takes place by different ways: while the classical pathway of mast cell activation is through Immunglobulin (Ig)E-Fce receptor crosslinking (Beaven \& Metzger, 1993), the alternative way includes the activation of pattern recognition (such as TLRs) (McCurdy et al., 2001; Supajatura et al., 2002) or complement receptors (Prodeus et al., 1997). Activated MCs have a capacity to secrete a large variety of inflammatory mediators such as a range of bioactive amines and proteoglycans; histamine, which is a potent vasodilator and enhance vascular permeability; lipid mediators such as prostaglandins and leukotrienes, which are potent chemoattractants for CD8+ T cells and a large set of chemokines and cytokines, which are able to recruiting and activating leukocytes (Galli et al., 2005). Furthermore, they promote the vascular endothelial expression of selectins and adhesion molecules, which indirectly support leukocyte recruitment (Meng et al., 1995). MCs also have a direct immunoregulatory role by interacting with T cells, B cells, and dendritic cells (Galli et al., 2005). They are able to present antigens to naive $T$ cells in an MHC-restricted manner (Dimitriadou et al., 1998) and influence T cell differentiation towards Th2 (by IL-4, IL-10 and histamin) (Jutel et al., 2002) or Th17 phenotype (Nakae et al., 2007). Furthermore, MCs seem to be essential to induce the development of Tregs that limit the infiltration of autoreactive $T$ cells, and mediate peripheral tolerance (Lu et al., 2006). Experimental studies suggest that degranulation of MCs leads to the release of TGF- $\beta$, TNF- $\alpha$, MCP-1, fibroblast growth factor (FGF), vascular endothelial growth factor (VEGF), IL-4 and MMP-9 and a variety of unique proteases, principally tryptase and chymase (Holdsworth \& Summers, 2008), which contribute to progressive fibrogenesis (Cairns \& Walls, 1997). Tryptase is prestored in cytoplasmic granules of MCs and has potent proteolytic activity against ECM proteins (Payne \& Kam, 2004) and it supports the proliferation of fibroblasts and the synthesis of 
type I collagen (Cairns \& Walls, 1997). Chymase can activate MMP-2 and MMP-9, disrupt of tight junction proteins (Scudamore et al., 1998) and involved in the activation of reninangiotensin system (Huang et al., 2003). On the other hand MCs can also participate in tissue remodeling and restoration of the normal kidney homeostasis (Bradding et al., 2006; Bankl \& Valent, 2002). For example heparin produced by MCs is a potent anti-thrombotic, anti-inflammatory, anti-coagulant and anti-fibrotic agent, which is able to modulate renal fibroblast proliferation by arachidonic acid-derived lipid mediators such as leukotriene and prostaglandin (Clarkson et al., 1998) or by inhibition of TGF- $\beta$ (Miyazawa et al., 2004).

\subsection{T lymphocytes}

$\mathrm{T}$ lymphocytes are main effector cells of adaptive immune system and activated by specific antigen stimuli. Although macrophages constitute the predominant infiltrating cell population of the injured kidneys, increased number of $\mathrm{T}$ lymphocytes were also observed in chronic renal diseases. It is also well known that the degree of tubulointerstitial fibrosis is related to the number of infiltrating $\mathrm{T}$ cell, implying their role in the fibrotic process (Tapmeier et al., 2010). In accordance with this observation Niedermayer et al. have shown that lymphocyte deficiency cause a substantial reduction in collagen I deposition in the obstructed kidney (Niedermayer et al., 2009). In the early phase of renal injury chemoattractants released by damaged and infiltrating immune cells directing the migration of activated $\mathrm{T}$ lymphocytes into the injured tissue. In this process CC (RANTES/CCL5), CXC (IP-10/CXCL10) chemokines, MIPs, lipid mediators (leukotriene) and anaphylatoxic complement fragments play a pivotal role (Kuroiwa et al., 2000). The activation of $\mathrm{T}$ cells occurs by antigenspecific manner. Antigens are presented by MHC molecules expressed on the cell surface of antigen-presenting cells (dendritic cells, macrophages, B cells) and recognized by $\mathrm{T}$ cell receptor/CD3 complex, which are the specific antigen-recognizing receptors of $\mathrm{T}$ lymphocytes. There are two different populations of the effector $\mathrm{T}$ lymphocytes: while CD8+ cytotoxic T cells have a direct cell-killing activity, Th cells are characterized by the expression of $\mathrm{CD} 4$ costimulator molecule and release a wide range of cytokines to mediate immune functions. Endogen antigens are presented on MHC type I molecules to CD8+ T cells, while exogen antigens are presented on MHC type II molecules to CD4+ T cells. After antigen recognition T cells become activated effector T cells or longlived memory $\mathrm{T}$ cells. Cytokines released by the antigen presenting cells, such as macrophages and dendritic cells play a pivotal role in polarization of CD4+ $\mathrm{T}$ cells to different Th subtypes: IL-12 and IL-18 as a cofactor promote the generation of Th1 phenotype and the proinflammatory Th1-type cellular immune response. In Goldblatt hypertensive rats antihypertensive therapy induces a significant proinflammatory Th1 immune response with increased Th1-type chemokine (IP-10) and cytokine (IFN- $\gamma$ ) expression (Steinmetz et al., 2007). Similarly, the absence of Ang II type 1 receptor (AT1) in AT1R KO mice is associated with Th1-type immune response (Ouyang et al., 2005). IFN- $\gamma$, which is secreted by Th1 cells (and also other immune cells) is required to the classical activation of M1-type macrophages, which have proinflammatory but not fibrotic properties. These data suggest that Th1 cells mediate proinflammatory, rather than fibrotic effects. Th2 lymphocytes may mediate the activation of alternatively activated M2 type macrophages by producing IL-4, IL-5, IL-10, IL-13 and TGF- $\beta$. The activated M2 macrophages may promote fibrotic diseases and mediate collagen synthesis, suggesting the role of Th2-mediated immune response in fibrotic process (Wynn, 2004). Beside Th1-Th2 
polarization, the Treg-Th17 axis is the other important player of immune response observed in chronic kidney diseases. Foxp3+ Treg have immunoregulatory and anti-inflammatory role via release of TGF- $\beta$ and IL-10 (Mu et al., 2005). IL-10-secreting Treg cells suppress the activation of Th1, Th2 and Th17 cells, thus ameliorate the severity of inflammatory process, for example in mice with lupus nephritis (Zhang et al., 2010). Treg cells may promote the polarization of monocytes towards M2 macrophages, which may mediate profibrotic effects. Th17 cells produce IL-17 (IL-17A), IL-17F, IL-21, IL-22 which may promote inflammation by directly causing tissue injury and enhancing secretion of proinflammatory cytokines and chemokines by resident cells. This results in augmented infiltration of leukocytes, mainly neutrophils to the injured tissue where they induce inflammation (Turner et al., 2010). Dudas et al. described that IL-17A also mediate proinflammatory/profibrotic activity on proximal tubule epithelial cells that may contribute to allograft rejection (Dudas et al., 2011). In general both CD8 and CD4 positive cells may directly stimulate the migration, proliferation and differentiation of renal cells resulting in the accumulation of a-SMA positive myofibroblasts. $T$ cells may also act indirectly on the infiltrating macrophage population by inducing a profibrotic phenotype, which, in turn, secrete pro-proliferative and profibrotic cytokines and growth factors (for example PDGF, TGF- $\beta$ ). Moreover, T cells may directly interact with epithelial cells to induce secretion of cytokines and growth factors that, in turn, act on fibroblasts (Strutz \& Neilson, 1994).

\subsection{B lymphocytes}

B lymphocytes are effector cells of the adaptive immune system. B cells are activated through their specific antigen-recognizing $B$ cell receptor complex on $T$ cell dependent or independent manner. Activated B cells mature to plasma cells and mediate humoral immune response by producing specific antibodies or differentiate into long-lived memory $\mathrm{B}$ cells. B cells themselves may also act as antigen presenting cells and influence $\mathrm{T}$ cell response in the lymphoid folliculi. B cells may contribute to renal fibrosis in different ways, but their exact role in the process is less known. On the one hand autoantibodies produced by B cells are largely present in immune complexes, which may accumulate in the glomeruli in severe autoimmune and kidney diseases and activate innate immune cells by their immunoglobulin Fc receptors. Autoantibody synthesis could also occur after bacterial or viral infection, oxidant synthesis, or T cell mediated immunity.

On the other hand infiltrated B cells have an important role in renal interstitial inflammation: indeed, Heller et al. found that mature B cells formed a prominent part of the renal interstitial infiltrating cells in renal biopsies from patients with acute or chronic interstitial nephritis and IgA nephropathy. The expression of CXCL13, which is a chemoattractant for B cells, was elevated in these inflamed kidneys. CXCL13 level was correlated with the infiltrated B cell number and contributed to the formation of intrarenal lymphoid follicle-like structures, which might represent an intrarenal immune system (Heller et al., 2007). B cell activating factor - which belongs to TNF superfamily - has an important role in the development and survival of B lymphocytes. Xu et al. demonstrated in kidney allograft biopsies, that B cell activating factor expression may be associated with the development of antibody-mediated allograft rejection and renal interstitial fibrosis in kidney transplants (Xu et al., 2009). Moreover, IgG4-associated tubulointerstitial nephritis is characterized by high levels of serum IgG4 and IgE and a significant number of IgG4producing plasma cells in the renal fibrotic lesions (Saeki et al., 2007; Raissian et al., 2011). 


\subsection{Complement activation}

Complement system is an essential, and conserved part of the immune system, defends the host against invading pathogens, prevents immune complex disease and aids the acquired immune response. It consists of a number of small proteins, which are generally synthesized by the liver and normally circulating in the blood as inactive precursors. In response to several triggers, proteases (convertases) cleave the specific proteins of the complement system and initiate a cascade of further cleavages. Finally the activated complement proteins as multimeric membrane attack complexes bind to the surface of target cells and and lyse them (Lesher \& Song, 2010). Immune complexes contain a large amount of complement fragments, which may accumulate in the glomeruli in different autoimmune diseases and activate the innate immune cells by their complement receptors. Detection of complement deposition in the glomerulus using immunochemistry has become an important element of the histological analysis of renal biopsies, and is key to the diagnosis of many types of glomerulonephritis. In recent years it has become evident that complement activation is involved in the pathogenesis of other types of renal disease including progressive tubulointerstitial fibrosis (Brown et al., 2007). For example, deficiency in the expression of C5 (Boor et al., 2007), C4d (Xu et al., 2009) or C6 (He et al., 2005) complement fragments caused reduced renal damage and interstitial fibrosis in different kidney diseases. Blocking the receptors of the potent anaphylatoxins $\mathrm{C} 5 \mathrm{a}$ and $\mathrm{C} 3 \mathrm{a}$ lead to significantly reduced renal leukocyte infiltration, tubulointerstitial inflammation and fibrosis (Boor et al., 2007; Bao et al., 2011).

\section{Important molecular pathways}

In addition to the above mentioned activation of the immune cells the increased amount of different cytokines and growth factors are also participate in the accumulation of the ECM in renal the interstitium along the tubules. To date more than a dozen different cytokines (IFNY, IL-1), growth factors (TGF, connective tissue growth factor, bone morphogenic protein, Insulin-like growth factor-1, TNFa) and other molecules (Ang II, NO) have been demonstrated to induce interstitial inflammation, maturation of myofibroblasts and degradation or production of ECM. Here we are going to summarize our knowledge about TGF $\beta$, Ang II and PDGF and their downstream signaling pathways.

\subsection{Transforming Growth Factor $\beta$ (TGF $\beta$ )}

TGF $\beta$ is a member of the TGF $\beta$ superfamily that include activins, inhibins and bone morfogenic proteins (Peng, 2003). In the healthy kidney TGF $\beta$ participate in the maintaining of the homeostasis. However, when the kidney is exposed to an injury then TGF $\beta$ is excessively produced by the resident renal cells and also by the infiltrating leukocytes (Border \& Noble, 1993; Coimbra et al., 1996; Eddy, 2000). Fukuda et al. (Fukuda et al., 2001) using in situ hybridization and immunohistochemistry demonstrated that TGF $\beta 1$ is mainly expressed by mesangial and epithelial cells of the glomeruli and the distal tubules in the healthy kidneys. Following UUO they observed increased TGF $\beta 1$ expression in the renal tubular epithelial cells of the renal cortex and outer medulla and also in the infiltrating macrophages. Indeed similar upregulation of TGF $\beta$ is present in every animal model of chronic renal disease and also in humans (Ketteler et al., 1994). 
TGF $\beta 1$ and its isoforms (TGF $\beta 2$ and 3) are secreted as precursos in a complex with latent TGF $\beta$ binding proteins. TGF $\beta$ become active when it is cleaved by plasmin, thrombospondin-1 or reactive oxygen species and thus dissociated from latent TGF $\beta$ binding proteins. The activated TGF $\beta$ then form dimers and bind to their type I and II cellsurface serin/threonine kinase receptors (TBR I and TBR II, respectively). So far two TBR I (activin like receptor kinase 1 and 5) and one TBR II (TGFBR2) have been have been shown to bind TGF $\beta$. TGF $\beta$ first binds to the constitutively active TBR II followed by the phosphorylation of the glycine/serin rich domain of the TBR I to create activated receptor heterodimer. Subsequently the activated receptor complex phosphorilates the downstream signaling mediators such as SMAD2/3, ERK1/2, Jun N-terminal Kinase 1/2 (Matsuzaki \& Okazaki, 2006). In the injured tissue TGF $\beta$ through its activated signaling pathways can trigger the increased production and decreased degradation of ECM (Pohlers et al., 2009) and thus the renal fibrosis. Koesters et al. showed marked peritubular fibrosis in the double transgenic mice overexpressing TGF $\beta 1$ in their tubular epithelial cells (Koesters et al., 2010). They observed the proliferation of the peritubular cells and the deposition of collagen type I rich ECM. Moreover, they observed the TGF $\beta 1$ dependent autophagy of the tubular cells which may represent a novel mechanism of tubular decomposition. On the other hand Isaka et al. demonstrated that introduction of antisense oligodeoxynucleotides against TGF $\beta 1$ into interstitial fibroblasts block the interstitial fibrosis in rats with unilateral ureteral obstruction (Isaka et al., 2000). Similarly, Miyajima et al. observed that administration of neutralizing anti-TGF $\beta 1$ antibody attenuate the tubular apoptosis in a rat model of UUO (Miyajima et al., 2000). Also Decorin, which is an ECM protein that bind TGF $\beta$, or soluble TGF $\beta$ receptor have been also shown to inhibit renal fibrosis (Peters et al., 1997; De Heer et al., 2000).

\subsection{Renin-Angiotensin System}

The RAS is the most important regulator of blood pressure, fluid and electrolyte homeostasis. The different components of the Renin-Angiotensin System, such as angiotensinogen, renin, AngI, angiotensin converting enzyme (ACE) Ang II, aldosterone and Ang II type I and II (AT1, AT2, respectively) receptors are all present in the kidney. Renin acts on angiotensinogen to form AngI, which is then converted by ACE to Ang II. The effects of Ang II are mediated by two high affinity receptors, AT1 and AT2. Since the overall abundance of AT1 receptors significantly exceeds that of AT2 type receptors in the adult kidney the most effects of Ang II are mediated through the AT1 receptor (Siragy, 2004). AT1 receptors are distributed on the luminal surface of the renal tubules, including proximal tubule, thick ascending limb of loop of Henle, distal tubule, macula densa and collecting duct (Allen et al., 2000). Recently the urinary angiotensinogen (Kim et al., 2011) and the intrarenal Ang II level (Del Prete et al., 2003) have been demonstrated to correlate with the severity of the chronic renal disease. As Ang II plays a key role in regulation of vascular tone (Cockcroft et al., 1995) and may induce proteinuria (Ren et al., 2011), oxidative stress, inflammation and renal fibrosis (Benigni et al., 2010) it is not surprising that ACE inhibitors or AT1 receptor antagonists have a renoprotective effect, which is independent from their antihypertensive effect (Mallamaci et al., 2011). Actually, the captopril trial on patients with type I diabetic nephropathy patients has shown a $50 \%$ reduction in the end point of death by captopril administration (Lewis et al, 2003). Although the clinical relevance of Ang II in chronic renal disease is obvious, its precise role is still unclear. It is well known that Ang II may induce EMT on the epithelial cells in vitro. However, since the significance of in vivo 
EMT is strongly questioned the in vivo relevance of Ang II on EMT is also questionable. Recently Kang et al. revealed that Ang II may decrease the NF-E2-related factor 2 (Nrf2) mediated signaling in murine renal epithelial TCMK-1 cells (Kang et al., 2011). Nrf2 is a transcriptional factor which by binding to the antioxidant response element on the promoter of different antioxidant genes can induce their expression. Kang et al. suggested that Ang II by inducing activating transcription factor 3 expression could inhibit the Nrf2 mediated upregulation of the antioxidant genes. Ang II increases vascular permeability via the release of prostaglandins and VEGF; contribute to the recruitment of inflammatory cells into the tissue through the regulation of adhesion molecules, chemokines (MCP-1, RANTES) and other molecules (osteopontin, see above) by resident cells; could directly activate infiltrating immunocompetent cells by cytokines (such as IL-6). AT1R or AT2R blockade (Esteban et al., 2003; Kellner et al., 2006) or treatment with ACE inhibitors (Ishidoya et al., 1995) greatly reduced monocyte/macrophage infiltration in short-term UUO, and AT1R-deficient macrophages have impaired phagocytic function (Nishida et al., 2002). Finally Ang II also may increase the expression of other molecules that play a pivotal role in organ fibrosis inducing TGF $\beta$, TNFa or PDGF or bFGF (Rüster \& Wolf, 2011). Moreover Ang II can potentiate the effect of TGF $\beta$ on the expression of SMA in TCMK-1 cells. Furthermore, AngII participates in tissue repair and remodeling, through the regulation of cell growth and matrix synthesis (Suzuki et al., 2003).

\subsection{Platelet Derived Growth Factor (PDGF)}

PDGF is a growth factor that regulates multiple cell function, such as cell growth (Bonner, 2004) or division and in particular in formation of blood vessels (Hellberg et al., 2010). Recently, its role in organ fibrosis has been also suggested (Trojanowska, 2008). PDGF family consist of five homo- or heterodimeric growth factors (PDGF-AA, -AB, -BB, -CC and DD). PDGF-A has two splice variant, a longer $(\approx 16 \mathrm{kD})$ which is retained to the cell surface and a shorter, which is released into the extracellular space. PDGF-AA and -BB can bind to different ECM proteins. PDGF-CC and -DD were identified just recently. PDGF-CC and -DD are secreted in a latent form and cleavage of the $\mathrm{N}$ terminal CUB (complement subcomponent $\mathrm{C} 1 \mathrm{r} / \mathrm{C} 1 \mathrm{~s}$, Uegf and Bmp1) domain is required for their activation. While PDGF-CC is activated by tissue type plasminogen activator and plasmin PDGF-DD is activated by urokinase type plasminogen activator. Many inherent renal cell express one or more PDGF isoforms, such as pericytes (Winkler et al., 2010), podocytes (Changsirikulchai et al., 2002), endothelial (Eitner et al., 2003), tubular epithelial (Eitner et al., 2002) and smooth muscle cells (Seifert et al., 1998). The different isoforms of PDGF bind to the homo- or heterodimeric tyrosine kinase receptors (PDGFR- $\alpha a,-\beta \beta$ and $-\alpha \beta$ ). The specifity and affinity of the different PDGF monomers to the $\alpha$ or $\beta$ chain of the receptor PDGFRs are different. While PDGF-A can bind to the $\alpha$, PDGF-B to the $\alpha$ and $\beta$ chains. The receptor affinity of PDGF-C and -D is less characterized, but it is likely that similarly to PDGF-B they can bind to the $\alpha$ and $\beta$ chain as well. Upon receptor binding the $\alpha$ and $\beta$ chains dimerize and possesses tyrosine kinase activity. After autophosphorylation the PDGFRs provide docking site for downstream signaling molecules containing SH2 (Floege J, 2008), SH3, PTB, PH (Andrae et al., 2008) and other domains thus activating several signaling pathways such as MAPK, PLCY or PI3K (Ostendorf et al., 2011). Increased expression of the different PDGF isoforms was observed in most if not all animal models of kidney injury. PDGFR-a chain, which is the receptor for PDGF-A and $-\mathrm{C}$ is widely expressed in the different renal cell 
types, such as myofibroblasts, mesangial and smooth muscle cells (Alpers et al., 1993). Interestingly, while infusion of high doses of PDGF-A $(5 \mathrm{mg} / \mathrm{kg})$ did not induced renal lesion (Tang et al., 1996) inhibition of PDGF-C with a neutralizing antibody exhibited a significant reduction of renal fibrosis, myofibroblast accumulation and decreased leukocyte infiltration in a mice model of UUO (Eitner et al., 2008). PDGF-BB has a central proliferative effect on the mesangial cells. Actually infusion of PDGF-BB into of healthy rats led to increased mesangial cell proliferation and accumulation of the mesangial matrix (Tang et al., 1996). More recently, the role of PDGF has been suggested in the transformation of pericytes, the main source of myofibroblasts, into myofibroblasts following kidney injury (Chen et al., 2011). Inhibition of PDGFR- $\alpha$ or PDGFR- $\beta$ signaling with a neutralizing antibody or with Imatinib, a PDGF tyrosine kinase inhibitor, treatment the UUO induced differentiation and proliferation of the pericytes decreased. The treatment of the animals with a neutralizing antibody against PDGFR- $\alpha$ or PDGFR- $\beta$ reduced the UUO induced macrophage infiltration, renal TGF $\beta$, PDGF and CCL2 expression and renal fibrosis. Hence PDGFR- $\alpha$ and PDGFR- $\beta$ are potential candidates for antifibrotic therapy in the future.

\section{Origin of myofibroblasts}

Understanding the origin of myofibroblasts in the kidney is great interest because these cells are responsible for scar formation in fibrotic kidney diseases. Myofibroblasts have migratory capacity, are resistant to apoptosis, and can produce different components of the extracellular matrix, growth factors, cytokines and therefore contribute to organ fibrosis and to the maintenance of inflammation (Zeisberg et al., 2008). Actually, in the healthy kidney there are no known endogenous myofibroblasts. In the fibrotic kidney (as in other organs) the origin of the renal myofibroblast is still controversial, however there are some hypotheses. Recently the derivation of myofibroblasts from epithelial or endothelial cells, fibrocytes and pericytes has been suggested (Fig. 1.).

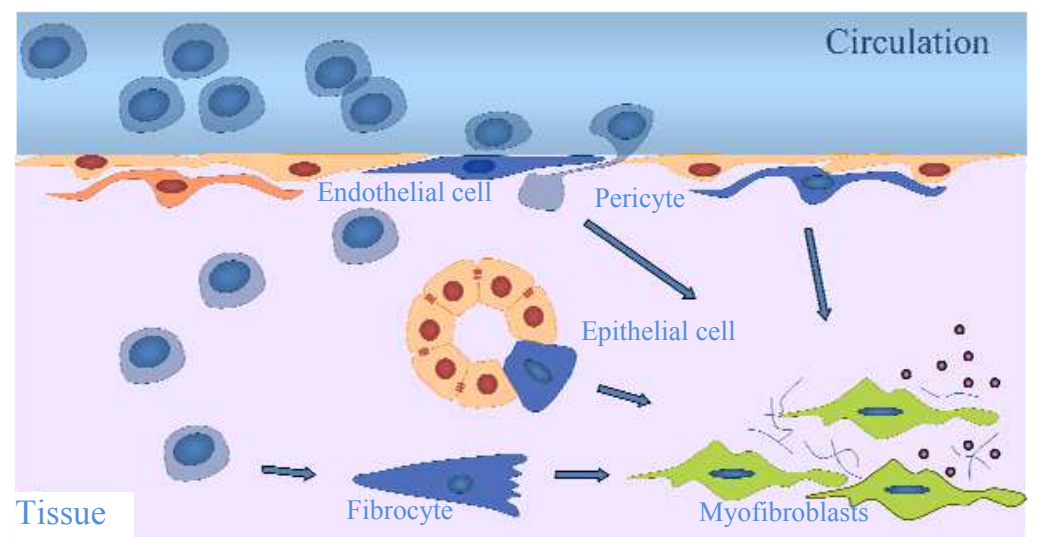

Fig. 1. Different possible origins of the myofibroblasts. There are different hypothesis about the possible origin of the myofibroblasts, which are effector cells of the organ fibrosis. The derivation of the myofibroblasts from endothelial and epithelial cells, from fibrocytes and pericytes (also known as perivascular cells, resident fibroblast or Rouget cells) has been suggested. 


\subsection{Epithelial-mesenchymal transition (EMT)}

A hypothesis that recently has become popular is the mesenchymal transition of the renal tubular epithelial cells. The process when the epithelial cells lose their polarity and epithelial adhesion properties and starts the de novo synthesis of mesenchymal markers, such as aSMA is the so called EMT. This process is already well known in different physiological and pathological processes, notably in embryogenesis, carcinogenesis (Kalluri \& Weinberg, 2009). The first remarkable evidence of EMT in the fibrotic kidney was demonstrated by $\mathrm{Ng}$ et al ( $\mathrm{Ng}$ et al., 1998). They investigated the localization of aSMA after 1-21 weeks of 5/6 nephrectomy of Sprague-Dawley rats. In normal kidneys in situ hybridization and immunohistochemical staining revealed the mRNA or protein expression of aSMA only in the vascular smooth muscle cells. Later on the $3^{\text {rd }}$ week after the $5 / 6$ nephrectomy, mRNA and protein expression of aSMA was present in the proximal tubular epithelial cells (TEC) as well. Indeed they observed a gradually increasing number of aSMA+ TEC peaking at week 9. Moreover, about $70 \%$ of the aSMA+ TEC were proliferating based on their proliferating cell nuclear antigen positivity. Finally these cells became elongated separated from their neighboring cells and appeared to migrate into the renal interstitium through the damaged basement membrane. These original observations were confirmed at the ultrasructural level of the renal tubules by electron microscopy. They found that in the early transformed TECs contain large round or oval shaped nucleus, several mitochondria indicating the activation of these cells. Characteristic microfilaments and dense bodies (stress fibers) were present in the transformed TECs, lying next to the damaged TBM. Later in advanced state of EMT TECs exhibit elongated morphology and abundant microfilaments and dense bodies. At this stage microfilaments are diffusely fill the entire cytoplasm of TECs. Later Iwano et al. strengthened the hypothesis of in vivo EMT using genetic fate mapping method (Iwano et al., 2002). Briefly, they developed transgen mice that express Cre recombinase under the promoter of $\gamma \mathrm{GT}$. As $\gamma \mathrm{GT}$ is a brush border protein, its promoter is active only in the proximal TECs (PTEC). These yGT-Cre mice were then bred with a R26R reporter mice (Fig. 2). In the PTECs of the bigenic mice the expressed Cre recombinase mediates the excision of the loxP stop cassette and activate the expression of $\beta$ galactosidase from the gene of LacZ. Thus irreversibly marking the PTECs with $\beta$ galactosidase, despite the subsequent phenotypic changes.
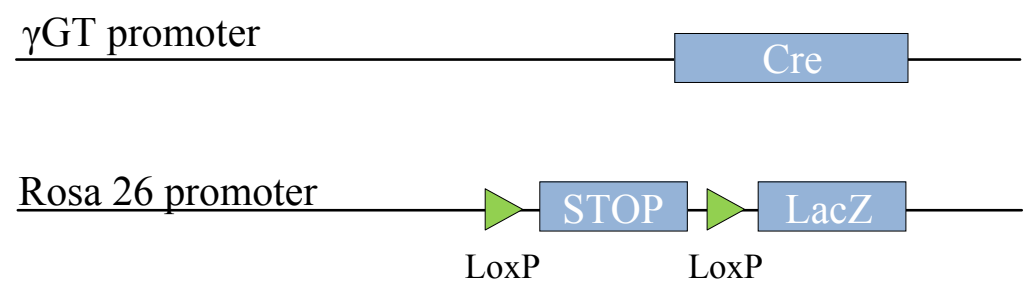

Fig. 2. Model of transgen mice that express Cre recombinase under the promoter of yGT. These yGT-Cre mice were then bred with a R26R reporter mice.

Later, ten days after UUO the PTECs of the double transgenic, yGT-Cre; R26R mice started to express (beside $\beta$ galactosidase) fibroblast specific protein-1 (FSP-1), suggesting the EMT of TECs (Fig. 3/b; LacZ-red and FSP1-green, merge-yellow). Some of these FSP-1 and $\beta$ 
galactosidase double positive PTECs also began to take an elongated shape of myofibroblasts (Fig. 3/b; arrows). Moreover, these double positive cells appeared in the fibrotic tissues surrounding the tubules (Fig. 3/c and d). Finally by counting the FSP1 and LacZ immunopositive cells in the renal interstitium, they suggested that after 10 days of UUO about $36 \%$ of the myofibroblasts originate from the renal tubular epithelial cells.

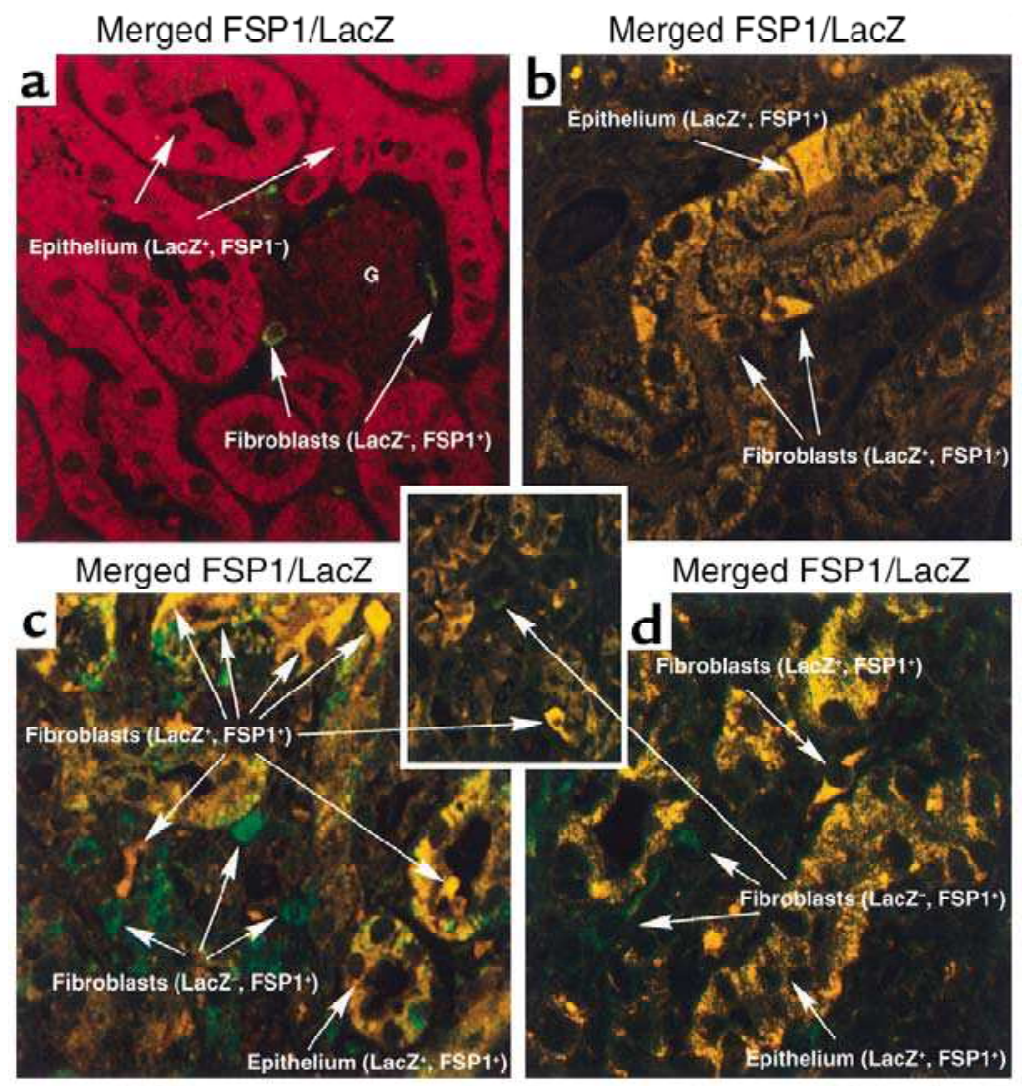

Fig. 3. Confocal microscopy images of contralateral (a) and injured (b, c and d) kidneys 10 days after the UUO (Iwano et al., 2002). Proximal tubular epithelial cells are stained with an anti- $\beta$ galactosidase antibody (red) and the fibroblasts with an anti-FSP1 antibody (green). $(b, c, d)$ Ten days after the onset of UUO the $\beta$ galactosidase positive PTECs also expressed FSP-1 ( $\beta$ galactosidase+/FSP-1+ PTECs cells staining yellow), suggesting the mesenchymal transition of cells. (b, c, d) Some of these FSP-1+ PTECs (arrow) had the elongated shape of myofibroblasts, and appeared in the fibrotic tissues surrounding the tubules. (After Iwano et al., 2002)

Subsequently numerous in vitro studies confirmed the original observation of $\mathrm{Ng}$ ( $\mathrm{Ng}$ et al., 1998) and Iwano et al. (Iwano et al., 2002). These studies on different cell lines (HK-2, HEK298, NRK) and on primer renal tubular epithelial cells have clearly shown that epithelial cells when exposed to hypoxia, reactive oxygen species, advanced glycation end 
products, pro-fibrotic cytokines, TGF- $\beta 1$, angiotensin II (ANGII), platelet-derived growth factor, epidermal growth factor and fibroblast growth factor-2 (Liu, 2010) growth factors or metalloproteinases (Yang \& Liu, 2001) may undergo EMT. During EMT these molecules activate different signaling pathways on a coordinated manner. As a result the Ras/Rho GTPase, Rho-activated kinase, c-Src tyrozin kinase, Integrin-linked kinase, Wnt-1, Smad 2 and 3, p38 mitogen-activated protein kinase, extracellular signal-regulated kinase (ERK) and phosphatidil-inositol-3 kinase (PI3K) signaling pathways can be activated (Thiery \& Sleeman, 2006). Activation of these signaling pathways leads to the phenotypical conversion of the TECs. During EMT TECs lose their cellular polarity, downregulate epithelial markers and acquire mesenchymal features, such as the de novo synthesis of a-SMA. Finally the epithelial cells are transformed to myofibroblasts as a determinative step in renal fibrosis (Iwano et al., 2002). In the 2008 EMT congress in Cold Spring Harbor according to the in vivo and in vitro findings this process that led to tissue scaring was defined as type II EMT. Based on these studies EMT has been widely accepted as one of the main mechanism by which myofibroblast formed during renal fibrosis. However the presence of this phenomenon, even on primer epithelial cells is evident in vitro, recently it has been questioned in vivo. Unfortunately, the results of Iwano et al. have not been confirmed by other groups. In contrast others using genetic fate mapping techniques were not able to demonstrate any evidence of EMT in vivo. Humphreys et al. developed two transgenic Cre driver mice that express bacterial Cre recombinase under the regulation of Six2 or HoxB7 promoters (Humphreys et al., 2010) (Fig. 4/A). Both Six2 and HoxB7 are transcriptional factors that transiently expressed during development. Six 2 is expressed only in those cells of metanephric mesenchyme that are fated to be epithelial cell of the proximal or distal tubules. HoxB7 is expressed in the cells of ureteric bund that are fated to be the cells of the collecting duct. These transgenic mice were bred with R26R reporter mice expressing $\beta$ galactosidase. In the kidney samples of the healthy Six2-Cre; R262 bigenic mice strong epithelial $\beta$ galactosidase activity was present in the podocytes and in the whole tubulus until the collecting duct. In case of HoxB7-Cre; R262 double transgenic mice this positivity was restricted to the epithelia of the collecting duct (Figure 4/B). Fourteen days after the UUO there was no change in the localization of $\beta$ galactosidase activity. $\beta$ galactosidase activity was present in the epithelial cell of the bigenic mice (Six2-Cre; R262 or HoxB7-Cre; R262), but none of the aSMA positive interstitial cells were positive for $\beta$ galactosidase activity. These results strongly suggest that epithelial cells do not leave their original place, behind the basement membrane and they do not migrate into the interstitium of the ureteral obstructed kidney.

Based on these conflicting data it is not evident whether in vivo EMT is an existing process in the fibrotic kidney or not. While in vitro data strongly suggest the existence of EMT in vivo studies of Humphreys et al. and others suggest that TECs do not invade the basement membrane and do not become real interstitial myofibroblasts (Humphreys et al., 2010). But are the in vitro and in vivo data really contradictory? Actually in vitro studies investigate the molecular mechanism of EMT but do not investigate the basement membrane invading capacity of the transformed cells. On the other hand in vivo experiments investigate the basement membrane invading capacity of the TECs but do not investigate the molecular changes of the TECs during the fibrotic process. So some scientists believe that the aim of the in vitro and in vivo studies is different and thus the results of these studies are not necessarily contradictory. 

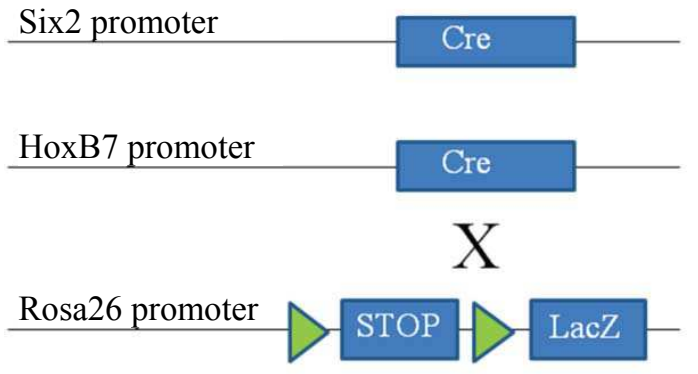

A.

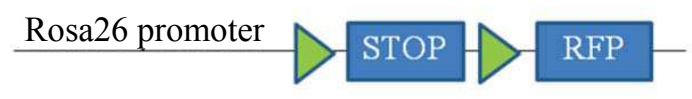

\section{control 14 days after UUO}
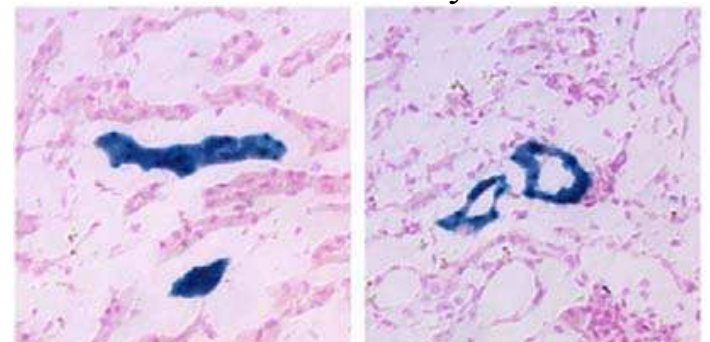

Six2-Cre; R26R . Six2-Cre; R26R

B.
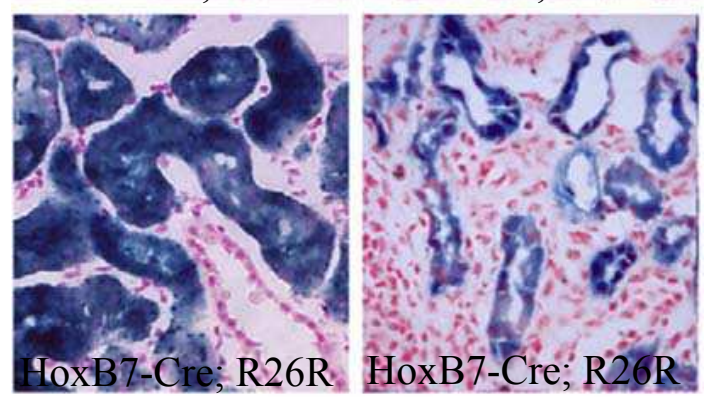

Fig. 4. Control and kidneys 14 days after the UUO from Six2-GC; R26R and HoxB7-Cre; R26R mice show no evidence for $\beta$ galactosidase activity in the renal interstitium. A: Double transgen Six2-GC; R26R mice activated Cre expression in the cells of the metanephric mesenchyme that are fated to become the cells of the renal tubules. Expression of Cre results in removal of the LoxP-STOP-LoxP sequence in epithelial cells, leading to permanent, heritable expression of $\beta$ galactosidase in epithelial cells. Similarly in HoxB7-Cre; R26R mice activation of Cre expression in the ureteric bud led to the expression of $\beta$ galactosidase in the epithelial cells of the collecting duct. B: Representative light microscopy images of X-gal stain indicating of $\beta$ galactosidase activity in the control (left) and in the obstructed (right) kidneys. (After Humphreys et al., 2002) 


\subsection{Endothelial-mesenchymal transition (EndMT)}

EndMT was first described during embryonic heart development, where mesenchymal cells of the endocardial cushion (a tissue that later gives rise to the cardiac septa and valves) arise from endothelial cells of the endocardium. Endothelium is a specialized type of a squamous type epithelium. Thus EndMT is a specific form of EMT. Simirarly to EMT during EndMT endothelial cells (EC) lose their endothelial markers and acquire markers of myofibroblasts. Studies on different organs have demonstrated the relevance of EndMT in the pathomechanism of organ fibrosis. Zeisberg et al. used Tie1 Cre; R26R bigenic mice to fate the EC during cardiac fibrosis (Zeisberg et al., 2007a). They have demonstrated that EC undergo phenotypic conversion and contribute to organ fibrosis. Similarly, Hashimoto et al. using Tie2 Cre; CAG-CAT-LacZ transgenic mice have shown that EC give a significant percent of myofibroblasts in bleomycin induced pulmonary fibrosis (Hashimoto et al., 2010). Recently, the importance of EndMT was suggested in different models of renal fibrosis as well. Zeisberg et al. investigated the contribution of endothelial cells to fibrosis in different animal models of CKD: 1 ) a mouse model of unilateral obstructive nephropathy; 2) a model of streptozotocin (STZ) induced DN; 3) a mouse model of Alport disease (COL4A3 KO, lack the collagen IV a3 chain). First they investigated the effect of UUO on the population of FSP1 or aSMA positive myofibroblast. Previously, it has been demonstrated that FSP-1 or aSMA identify distinct population of myofibroblast with a minimal overlap between the different populations (Zeisberg et al., 2007a, 2007b). One week after the ligation of the ureter the number of the FSP-1 or aSMA positive myofibroblast population increased. To investigate the possible endothelial origin of the myofibroblast double immunostaining were performed. The number of the CD31 (marker of the EC) and FSP-1 or CD31 and aSMA positive myofibroblasts were $36 \%$ or $25 \%$, respectively (Fig. 5).

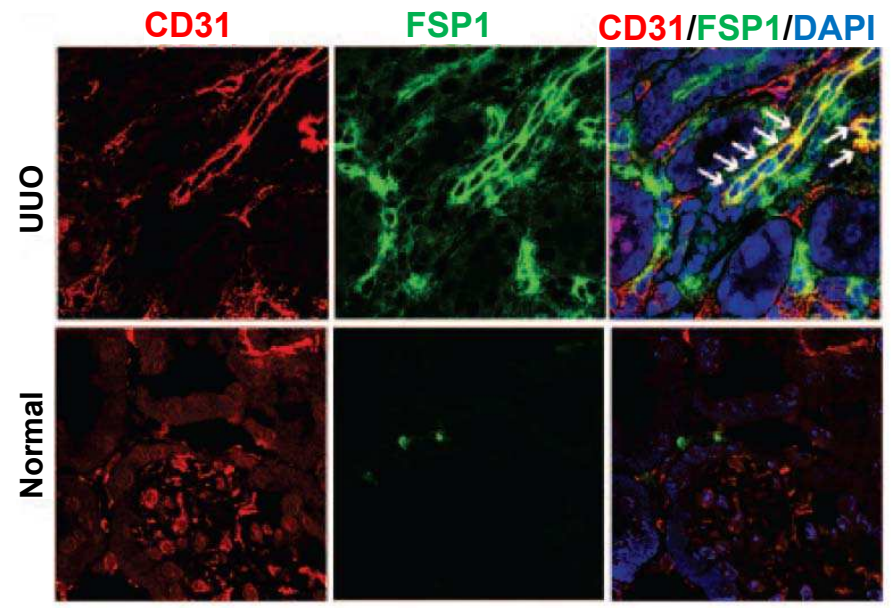

Fig. 5. Immune fluorescent staining to investigate the possible endothelial origin of the myofibroblast. CD31 (red) is a marker of ECs, FSP-1 (green) is that of myofibroblasts. (After work of Zeisberg et al., 2007).

To strengthen the endothelial origin of these double CD31 and FSP-1 or CD31 and aSMA myofibroblast they performed UUO in Tie2-Cre; EYFP double transgenic mice. In these mice 
cells of endothelial origin express yellow fluorescent protein (YFP). After UUO a substantial portion of FSP-1 or aSMA positive myofibroblast coexpressed YFP, suggesting their endothelial origin. These data strongly suggest that EndMT may account for a considerable percent of myofibroblasts in the mouse model of UUO. Zeisberg et al. also investigated the origin of myofibroblasts in a mouse STZ induced DN. They have demonstrated that 6 moths after the induction diabetes about $50 \%$ of the aSMA and $40 \%$ of the FSP-1 positive cells were also CD31 positive in the kidney, suggesting the relevance of EndMT in the fibrotic changes in DN. Finally, Zeisberg et al. investigated the origin of myofibroblast in COL4A3 KO mice, in a model of Alport syndrome. In these mice proteinuria, glomerulonephritis and tubulointersitial fibrosis starts at the $8^{\text {th }}$ week of age. In the investigated 22 weeks old mice strong interstitial fibrosis was present as revealed by the Masson Trichrome staining (MTS). In accordance with MTS the number of myofibroblast was elevated in COL4A3 KO compared to wild type mice. To investigate the origin these myofibroblast the coexpression of FSP-1 or aSMA and CD31 was investigated by double immunostaining. They found that about $45 \%$ of the aSMA and $60 \%$ of the FSP-1 positive myofibroblast were CD31 positive, suggesting the endothelial origin of these cells. In accordance with Zeisberg et al. Li and coworkers revealed the contribution of EndMT in the development of STZ induced renal fibrosis. They developed a Tie2Cre; EGFP mice to trace the localization of the cells with endothelial origin in a mice model of STZ induced DN. Tie2 is a pan endothelial marker which is expressed in EC during embryogenesis and thereafter during adulthood. In the bigenic mice Cre recombinase is expressed under the promoter of Tie 2 and mediates the excision of a loxP stop cassette thus activating the expression of EGFP. In accordance with other studies (Schlaeger et al., 1997; Koni et al., 2001; Limbourg et al., 2005) the Cre mediated recombination occurred mainly in the ECs, with only a little activity in other cells. In the normal kidneys of Tie2Cre; EGFP mice CD31 staining colocalized with the EGFP positive cells. However, 1 or 6 months after the induction of STZ induced DN $10.4 \%$ or $23.5 \%$ of renal aSMA positive interstitial myofibroblasts were EGFP positive, suggesting there endothelial origin. Apparently these studies clearly demonstrate the significant role of EndMT in the pathomechanism of renal fibrosis. However, ECs are specialized squamous epithelium and the similarities between EMT and EndMT is evident suggesting that EndMT is a specific form of EMT. So the question emerges why ECs can invade the basement membrane and become real interstitial myofibroblasts if epithelial cells can not.

\subsection{Pericytes, perivascular cells or resident fibroblasts}

The definition of pericytes (also known as Rouget cells), perivascular cells or resident fibroblasts in the kidney is still a matter of debate. Pericytes occurs around peritubular capillaries and postcapillary venules in the kidney. Pericytes characteristically line at the outer surface of EC and are covered fully or in part with capillary basement membrane thus fulfilling the major criterias of pericytes. These gaps of capillary basement membrane are frequently colocalise with the projections of pericytes, which are believed to be sites of intercellular communication (Grgic et al., 2011). Some projections of the pericytes also can reach the basement membrane of the TECs, make them similar or identical to the cells called resident fibroblast (Kaissling et al., 1996). Recently it has been suggested that activation of pericytes - which are relatively undifferentiated cells - may led to phenotype transformation of them into myofibroblasts. To investigate the potential role of pericytes as myofibroblast precursors Lin et al. generated a transgenic mice expressing GFP under the promoter of 
collagen type I, a1 (Lin et al., 2008). In these animals the presence of GFP labels, with high sensitivity, the collagen I, a1 producing cell. In healthy kidney of this, coll1a1-GFP mice peritubular capillaries were lined intermittently with collagen type I, a1 producing cells, which were subendothelial in a direct apposition with CD31 positive ECs and exhibited pedicle like attachment plaques suggesting the direct interaction of collagen type I, a1 producing cells with the ECs. These characteristics define these collagen type I, a1 producing cells as pericytes. In developed, but young, 12 days old animals the majority $(98,4 \%)$ of these cells also expressed chondroitin sulfate proteoglycan 4 (CSPG4), aSMA and PDGFR $\beta$ which are all known markers of pericytes. Later in healthy adult mice renal pericytes lost their CSPG4 and aSMA positivity with time. To investigate the contribution of the pericytes to renal fibrosis Lin et al. induced UUO in these coll1a1-GFP mice. In the kidney of diseased mice pericytes do not lose their CSPG4, aSMA and PDGFR $\beta$ positivity, rather their population expands. In this model of renal fibrosis 7 days after ureteral obstruction there was a close but imperfect correlation between the collagen 1, a1producing (GFP+) and aSMA positive interstitial cells. Actually 1\% of the GFP producing cell did not express aSMA and 25\% of the aSMA producing cells did not express GFP in the renal interstitium. These study of Lin et al. strongly suggest that the main source of the myofibroblasts are the collagen I, a1 producing cells, most likely pericytes in the obstructed kidneys. However, these data also suggest that a remarkable percent of the aSMA producing myofibroblasts may originate from other cells then pericytes. Later this group to strengthen their observations made a genetic fate mapping study to test that pericytes are the primary source of myofibroblasts in the UUO model of fibrosis. Humphreys et al. developed a transgenic Cre driver mice that express bacterial Cre recombinase under the regulation of forkhead box D1 (FoxD1) promoter (Fig.6.) (Humphreys et al., 2010). FoxD1 is a transcriptional factor that is transiently expressed during development in metanephric mesenchyme cells that are fated to become mesangial, vascular smooth muscle cells and pericytes. These transgenic mice were then bred with R26R reporter mice. In the kidney of the FoxD1-Cre; R262 bigenic mice mesangial and vascular smooth muscle cells and many PDGFR $\beta$ positive interstitial pericytes were detectable after $\mathrm{X}$-gal staining. Fourteen days after UUO they found a marked expansion of LacZ positive cells in the interstitium of the injured kidneys. These $\beta$ galactosidase positive cells were aSMA positive and all SMA positive cells exhibited $\beta$ galactosidase activity as well. Suggesting that there was no significant population of cells becoming myofibroblast, except the previously FoxD1 positive cells. However, following UUO FoxD1 transcripts were detected in the kidney samples of FoxD1-Cre; R262 bigenic mice. This means that not only the cells with the heritable marker of R26R mice, but also the de novo FoxD1 expressing cells are labeled with $\beta$ galactosidase. To circumvent this problem Humphreys B.D. et al developed FoxD1-GCE transgen mice, in which Cre recombinase is expressed under FoxD1 promoter in a tamoxifen-inducible manner. These mice were then bred with R26R reporter mice. FoxD1GCE; R26R mice that received tamoxifen during the nephrogenesis had $\beta$ galactosidase positive cells in the renal interstitium which also expressed PDGFR $\beta$ and were negative for aSMA (myofibroblast), CD31 (endothelial cell) or F4/80 (macrophages) defining them as pericytes. However, it should be noted that in FoxD1-GCE; R26R mice approximately $20 \%$ of pericytes were labeled with $\beta$ galactosidase activity. Ten days after UUO all $\beta$ galactosidase positive interstitial cells remained PDGFR $\beta$ positive and acquired expression of aSMA demonstrating that pericytes differentiated into myofibroblast. Nowadays the most accepted theory is the transformation of perycites into myofibroblasts. However, since these 
experiments are rather new it is still not known how the traditional fibrosis inducing factors like TGF $\beta-1$ or Angiotensin can alter the ECM producing capacity of myofibroblasts derived from perycites.

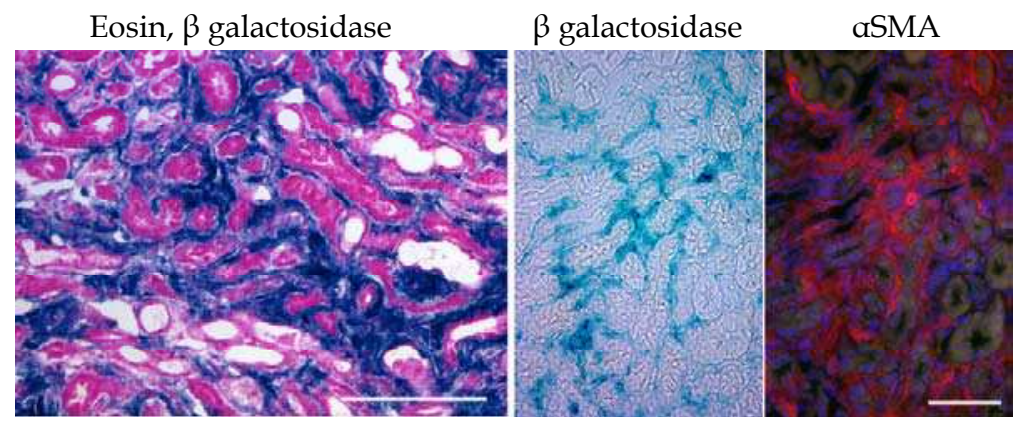

Fig. 6. Fourteen days after UUO a marked expansion of $\beta$ galactosidase positive cells (blue) was observed in the interstitium of the injured FoxD1-GC; R26R mouse kidneys. Merged light and fluorescence image show the co-expression of $\beta$ galactosidase (blue) with SMA (red) after UUO day 14. (After Humphreys et al., 2010).

\subsection{Bone marrow derived fibrocytes}

Fibrocytes are bone marrow (BM) derived mesenchymal cells (Mori et al., 2005; Kisseleva et al., 2006) that express the markers of hematopoietic stem cells, monocytes and fibroblasts (Yang et al., 2002; Mori et al., 2005; Abe et al., 2001). Previously these CD14+ and CD16fibrocyte precursors were termed as inflammatory monocytes (Gordon \& Taylor, 2005). In response to tissue damage these cells are released in high number from the BM and then migrate into the site of the injury. In the tissue most of these inflammatory monocytes then believed to differentiate into macrophages, dendritic cells (Tacke \& Randolph, 2006). However, a subpopulation of these CD14+ and CD16- cells can differentiate into other cells types, such as myoblasts, osteoblasts, epithelial, endothelial, neuronal cells (Zhao et al., 2003; Kuwana et al., 2003) or fibrocytes as an intermediate stage of differentiation into mature myofibroblasts. In vitro the co-culture of the CD14+ fibrocyte progenitors with $\mathrm{T}$ cells or stimulation of them with TGF $\beta 1$, PDGF, IL-4 or IL-13 promotes their maturation into fibrocytes. By contrast aggregated IgG, serum amyloid $\mathrm{P}, \mathrm{INF} Y$ or IL-12 inhibits the differentiation of CD14+ mononuclear cells into fibrocytes. Fibrocytes express CD34 and CD105 hematopoietic stem cell markers and MHC I and MHC II and the costimulatory molecules CD80 and CD86. Today the presence of CD45, CD34, or other myeloid antigen like CD11b and CD13 is considered to discriminate fibrocytes from leukocytes. Fibrocytes still do not express large amount of ECM (Chesney et al., 1998), however they produce ECM degrading enzymes, such as MMP9 (García-de-Alba et al., 2010). Fibrocytes can differentiate into myofibroblast in vivo (Mori et al., 2005; Schmidt et al., 2003). The further differentiation of the fibrocytes into myofibroblasts is stimulated by TGF $\beta 1$ and endothelin- 1 . The matured myofibroblasts then produce significantly more collagen then fibrocytes and express aSMA. Myofibroblasts also lose the CD34 and CD45 markers of fibrocytes. Despite our huge knowledge about the differentiation of CD14+ mononuclear cells into myofibroblast, the contribution of these BM derived cells to the population of myofibroblast is generally 
believed to be small. To investigate the contribution of fibrocytes to the population of myofibroblast Iwano M. et al. generated transgenic mice, in which EGFP is expressed under the promoter of FSP-1. In this experiment they used FSP-1 as marker of myofibroblast (Iwano $\mathrm{M}$ et al., 2002). The T cell depleted BM of these transgenic mice was intravenously injected into lethally irradiated Balb/c, wild type recipients. Thirty days after the BM transfer the chimeric mice underwent UUO. Finally, 10 days after the UUO the number of FSP-1 and EGFP double positive BM derived cells were counted in the injured and in the collateral, normal kidney samples. By counting several random cortical fields they found that about the $12 \%$ of the renal FSP-1 positive cells have BM origin in the normal and about $15 \%$ in the injured kidneys. These data suggest that 10 days after UUO only $3 \%$ of the FSP-1 positive myofibroblasts are originated from the BM. Others investigating the contribution of fibrocytes to the population of myofibroblast have found similar results. Lin et al. transplanted the BM cells of coll1a1-GFP mice into a lethally irradiated wild type recipient mice. In these chimeric mice all collagen type I, a1 producing cell with BM origin express GFP. To induce renal fibrosis UUO was performed on these chimeric mice. Interestingly, they found that 7 days after UUO only the $0.1 \%$ of the myofibroblast expressed the CD34 and CD45 markers of fibrocytes (Abe et al., 2001) in the chimeric mice. Taken together these data suggest that the contribution of CD14+ CD16- BM cells to the population of myofibroblasts is not significant. One week after the UUO only a few percent $(0.1-3 \%)$ of the myofibroblasts are originated from these CD14+ CD16- BM cells.

\section{Summary and concluding remarks}

Today there are different theories about the possible origin of the myofibroblasts that are responsible for scar formation in the injured kidney. A hypothesis that recently became popular is the mesenchymal transition of the renal tubular epithelial cells. During EMT epithelial cells undergo phenotypic conversion, which means that they lose their polarity, epithelial adhesion properties and starts the de novo synthesis of aSMA and other mesenchymal factors. This process is already well known in different physiological and pathological processes, notably in embryogenesis and carcinogenesis. In vitro experiments on different epithelial cell lines and on primer epithelial cells strongly suggest the existence of EMT based on their increased expression of aSMA, vimentin and decreased expression of E-cadherin. However, the role of EMT is controversial in renal fibrosis. Recently, Humphreys et al. using double transgenic animals, clearly demonstrated that tubular epithelial cells can not invade the basement membrane, suggesting that EMT does not lead to formation of myofibroblasts, actually not in vivo in the mice model of UUO. Interestingly, the concept of EndMT is widely accepted, despite that the endothelial cells are specialized squamous type epithelial cells suggesting that EndMT is only a specific form of EMT. Actually, the similarities between EMT and EndMT is evident. During the phenotype conversion endothelial or epithelial cells lose their original markers and start to express mesenchymal ones, such as aSMA. However, the question why endothelial cells can invade the basement membrane and epithelial cells can not is still unanswered. Today, perhaps the most accepted theory about the possible origin of myofibroblasts is the transformation of perycites into myofibroblasts. This observation is rather new and it is still not known how the traditional fibrosis inducing factors like TGF $\beta$ or angiotensin can alter the ECM producing capacity of myofibroblasts derived from perycites. Finally the contribution of CD14+ CD16- BM cells to the population of myofibroblasts is not significant. These cells are 
responsible for only $1-2 \%$ of the myofibroblast. There estimated number of patients with chronic kidney disease is over 2.5 millions in Europe and the number of patients on chronic renal replacement therapy number is continuously increasing. Thus research in that field has not only scientific impact, but has also important implications on general health and health care systems considering the quality of life in uremia and the socio-economic costs of renal replacement therapies. Actually regardless of the initiating cause (infection, autoimmune response, chemical insult, radiation or tissue injury etc.) fibrosis is the final common pathway for all progressive renal diseases. That is why it is so important to understand the complex interplay among immune cells, myofibroblasts precursors and renal cells. The development of new antifibrotic therapies is getting more and more important, and it requires the understanding of the cellular origin and precise role of myofibroblasts.

\section{Acknowledgments}

Ádám Vannay is holder of the János Bolyai Research grant; this work was supported by the János Bolyai Research Scholarschip of the Hungarian Academy of Sciences BAROSS GABOR REG_KM_INFRA_09 and OTKA 84087/2010.

\section{References}

Abe, R., Donnelly, SC., Peng, T., Bucala, R. \& Metz CN. (2001). Peripheral blood fibrocytes: differentiation pathway and migration to wound sites. J Immunol. 166(12):7556-62.

Allen, AM., Zhuo, J. \& Mendelsohn, FA. (2000). Localization and function of angiotensin AT1 receptors. Am J Hypertens. 13(1 Pt 2):31S-38S.

Alpers, CE., Seifert, RA., Hudkins, KL., Johnson, RJ. \& Bowen-Pope DF. (1993). PDGFreceptor localizes to mesangial, parietal epithelial, and interstitial cells in human and primate kidneys. Kidney Int. 43(2):286-94.

Anders, HJ. \& Ryu, M. (2011). Renal microenvironments and macrophage phenotypes determine progression or resolution of renal inflammation and fibrosis. Kidney Int. 80(9):915-25.

Anders, HJ. (2010) Toll-like receptors and danger signaling in kidney injury. J Am Soc Nephrol. 21: 1270-1274.

Andrae, J., Gallini, R. \& Betsholtz, C. (2008). Role of platelet-derived growth factors in physiology and medicine. Genes Dev. 22(10):1276-312.

Bankl, HC. \& Valent, P. (2002). Mast cells, thrombosis, and fibrinolysis: the emerging concept. Thromb Res 105:359-365.

Bao, L., Wang, Y., Haas, M. \& Quigg RJ. (2011). Distinct roles for C3a and C5a in complement-induced tubulointerstitial injury. Kidney Int. 80(5):524-34.

Beaven, MA. \& Metzger, H. (1993). Signal transduction by Fc receptors: The Fc epsilon RI case. Immunol Today 14: 222-226

Beil, WJ., Füreder, W., Wiener, H., Grossschmidt, K., Maier, U., Schedle, A., Bankl, HC., Lechner, K. \& Valent, P. (1998). Phenotypic and functional characterization of mast cells derived from renal tumor tissues. Exp Hematol. 26(2):158-69.

Benigni, A., Cassis, P. \& Remuzzi G. (2010). Angiotensin II revisited: new roles in inflammation, immunology and aging. EMBO Mol Med. 2(7):247-57.

Blackwell, TS. \& Christman, JW. (1997). The role of nuclear factor-kappa B in cytokine gene regulation. Am J Respir Cell Mol Biol. 17:3-9. 
Bonner, JC. (2004). Regulation of PDGF and its receptors in fibrotic diseases. Cytokine Growth Factor Rev. 15(4):255-73.

Boor, P., Konieczny, A., Villa, L., Schult, AL., Bücher, E., Rong, S., Kunter, U., van Roeyen, CR., Polakowski, T., Hawlisch, H., Hillebrandt, S., Lammert, F., Eitner, F., Floege, J. \& Ostendorf, T. (2007). Complement C5 mediates experimental tubulointerstitial fibrosis. J Am Soc Nephrol. 18(5):1508-15.

Border, WA. \& Noble, NA. (1993). Cytokines in kidney disease: the role of transforming growth factor-beta. Am J Kidney Dis. 22(1):105-13.

Bradding, P., Walls, AF. \& Holgate, ST. (2006). The role of the mast cell in the pathophysiology of asthma. J Allergy Clin Immunol. 117:1277-1284.

Bronte, V. \& Zanovello, P. (2005). Regulation of immune responses by L-arginine metabolism. Nat. Rev. Immunol. 5:641-654.

Brown, KM., Sacks, SH. \& Sheerin, NS. (2007). Mechanisms of disease: the complement system in renal injury--new ways of looking at an old foe. Nat Clin Pract Nephrol.3(5):277-86.

Busse, WW. (1998). Leukotrienes and inflammation. Am J Respir Crit Care Med. 157(6 Pt 1):S210-3.

Cairns, JA. \& Walls, AF. (1997). Mast cell tryptase stimulates the synthesis of type I collagen in human lung fibroblasts. J Clin Invest 99: 1313-1321

Cassatella, MA. (1999). Neutrophil-derived proteins: selling cytokines by the pound. Adv Immunol. 73:369-509.

Changsirikulchai, S., Hudkins, KL., Goodpaster, TA., Volpone, J., Topouzis, S., Gilbertson, DG. \& Alpers, CE. (2002). Platelet-derived growth factor-D expression in developing and mature human kidneys. Kidney Int. 62(6):2043-54.

Chen, YT., Chang, FC., Wu, CF., Chou, YH., Hsu, HL., Chiang, WC., Shen, J., Chen, YM., Wu, KD., Tsai, TJ., Duffield, JS. \& Lin, SL. (2011). Platelet-derived growth factor receptor signaling activates pericyte-myofibroblast transition in obstructive and post-ischemic kidney fibrosis. Kidney Int. [Epub ahead of print]

Chesney, J., Metz, C., Stavitsky, AB., Bacher, M. \& Bucala, R. (1998). Regulated production of type I collagen and inflammatory cytokines by peripheral blood fibrocytes. J Immunol. 160(1):419-25.

Chowdhury, P., Sacks, SH. \& Sheerin, NS. (2010). Endogenous ligands for TLR2 and TLR4 are not involved in renal injury following ureteric obstruction. Nephron Exp Nephrol. 115(4):e122-30.

Clarkson, MR., McGinty, A., Godson, C. \& Brady, HR. (1998). Leukotrienes and lipoxins: lipoxygenase- derived modulators of leukocyte recruitment and vascular tone in glomerulonephritis. Nephrol Dial Transplant 13:3043-3051.

Cochrane, AL., Kett, MM., Samuel, CS., Campanale, NV., Anderson, WP., Hume, DA., Little, MH., Bertram, JF. \& Ricardo, SD. (2005). J Renal structural and functional repair in a mouse model of reversal of ureteral obstruction. Am Soc Nephrol. 16(12):3623-30.

Cockcroft, JR., O'Kane, KP. \& Webb, DJ. (1995). Tissue angiotensin generation and regulation of vascular tone. Pharmacol Ther. 65(2):193-213.

Coimbra, TM., Carvalho, J., Fattori, A., Da Silva, CG. \& Lachat, JJ. (1996). Transforming growth factor-beta production during the development of renal fibrosis in rats with subtotal renal ablation. Int J Exp Pathol. 77(4):167-73.

Colvin, RB., Dvorak, AM. \& Dvorak, HF. (1974). Mast cells in the cortical tubular epithelium and interstitium in human renal disease. Hum Pathol 5:315-326.

Crisman, JM., Richards, LL., Valach, DP., Franzoni, DF. \& Diamond, JR. (2001). Chemokine expression in the obstructed kidney. Exp Nephrol. 9:241-248. 
De Heer, E., Sijpkens, YW., Verkade, M., den Dulk, M., Langers, A., Schutrups, J., Bruijn, JA. \& van Es, LA. (2000). Morphometry of interstitial fibrosis. Nephrol Dial Transplant. 15 Suppl 6:72-3.

Del Prete, D., Gambaro, G., Lupo, A., Anglani, F., Brezzi, B., Magistroni, R., Graziotto, R., Furci, L., Modena, F., Bernich, P., Albertazzi, A., D'Angelo, A. \& Maschio, G. (2003). Precocious activation of genes of the renin-angiotensin system and the fibrogenic cascade in IgA glomerulonephritis. Kidney Int. 64(1):149-59.

Dimitriadou, V., Mecheri, S., Koutsilieris, M., Fraser, W., Al-Daccak, R. \& Mourad, W. (1998). Expression of functional major histocompatibility complex class II molecules on HMC-1 human mast cells. J Leukoc Biol 64: 791-799

Dong, X., Bachman, LA., Miller, MN., Nath, KA. \& Griffin, MD. (2008). Dendritic cells facilitate accumulation of IL-17 $\mathrm{T}$ cells in the kidney following acute renal obstruction. Kidney Int. 74:1294-1309.

Dudas, PL., Sague, SL., Elloso, MM., Farrell, FX. (2011). Proinflammatory/profibrotic effects of interleukin-17A on human proximal tubule epithelium. Nephron Exp Nephrol. 117(4):e114-23.

Duffield, JS., Erwig, LP., Wei, X., Liew, FY., Rees, AJ. \& Savill, JS. (2000). Activated macrophages direct apoptosis and suppress mitosis of mesangial cells. J Immunol. 164(4):2110-9.

Duffield, JS., Tipping, PG., Kipari, T., Cailhier, JF., Clay, S., Lang, R., Bonventre, JV. \& Hughes, J. (2005). Conditional ablation of macrophages halts progression of crescentic glomerulonephritis. Am J Pathol. 167(5):1207-19.

Eddy, AA. (1995). Interstitial macrophages as mediators of renal fibrosis. Exp Nephrol. 3: 76-79.

Eddy, AA. (2000). Molecular basis of renal fibrosis. Pediatr Nephrol. 15(3-4):290-301.

Ehara, T. \& Shigematsu, H. (1998). Contribution of mast cells to the tubulointerstitial lesions in IgA nephritis. Kidney Int. 54:1675-1683.

Eis, V., Luckow, B., Vielhauer, V., Siveke, JT., Linde, Y., Segerer, S., Perez De Lema, G., Cohen, CD., Kretzler, M., Mack, M., Horuk, R., Murphy, PM., Gao, JL., Hudkins, KL., Alpers, CE., Gröne, HJ., Schlöndorff, D. \& Anders, HJ. (2004). Chemokine receptor CCR1 but not CCR5 mediates leukocyte recruitment and subsequent renal fibrosis after unilateral ureteral obstruction. J Am Soc Nephrol. 15(2):337-47.

Eitner, F., Bücher, E., van Roeyen, C., Kunter, U., Rong, S., Seikrit, C., Villa, L., Boor, P., Fredriksson, L., Bäckström, G., Eriksson, U., Ostman, A., Floege, J. \& Ostendorf, T. (2008). PDGF-C is a proinflammatory cytokine that mediates renal interstitial fibrosis. J Am Soc Nephrol. 19(2):281-9.

Eitner, F., Ostendorf, T., Kretzler, M., Cohen, CD., Eriksson, U., Gröne, HJ. \& Floege, J; ERCB-Consortium. (2003). PDGF-C expression in the developing and normal adult human kidney and in glomerular diseases. J Am Soc Nephrol. 14(5):1145-53.

Eitner, F., Ostendorf, T., Van Roeyen, C., Kitahara, M., Li, X., Aase, K., Gröne, HJ., Eriksson, U. \& Floege, J. (2002). Expression of a novel PDGF isoform, PDGF-C, in normal and diseased rat kidney. J Am Soc Nephrol. 13(4):910-7.

El-Koraie, AF., Baddour, NM., Adam, AG., El Kashef, EH. \& El Nahas, AM. (2001). Role of stem cell factor and mast cells in the progression of chronic glomerulonephritides. Kidney Int 60:167-172.

Esteban, V., Rupérez, M., Vita, JR., López, ES., Mezzano, S., Plaza, JJ., Egido, J. \& RuizOrtega, M. (2003). Effect of simultaneous blockade of AT1 and AT2 receptors on the NFkappaB pathway and renal inflammatory response. Kidney Int Suppl. S33-S38. 
Fadok, VA., Bratton, DL., Konowal, A., Freed, PW., Westcott, JY. \& Henson, PM. (1998). Macrophages that have ingested apoptotic cells in vitro inhibit proinflammatory cytokine production through autocrine/paracrine mechanisms involving TGF-beta, PGE2, and PAF. J Clin Invest 101: 890-898.

Fantone, JC. \& Ward, PA. (1985). Polymorphonuclear leukocyte-mediated cell and tissue injury: oxygen metabolites and their relations to human disease. Hum Pathol. 16(10):973-8.

Fellström, B., Klareskog, L., Heldin, CH., Larsson, E., Rönnstrand, L., Terracio, L., Tufveson, G., Wahlberg, J. \& Rubin, K. (1989). Platelet-derived growth factor receptors in the kidney-upregulated expression in inflammation. Kidney Int. 36(6):1099-102.

Floege, J., Eitner, F. \& Alpers, CE. (2008). A new look at platelet-derived growth factor in renal disease. J Am Soc Nephrol. 19(1):12-23.

Fukuda, K., Yoshitomi, K., Yanagida, T., Tokumoto, M. \& Hirakata, H. (2001). Quantification of TGF-beta1 mRNA along rat nephron in obstructive nephropathy. Am J Physiol Renal Physiol. 281(3):F513-21.

Galli, SJ., Kalesnikoff, J., Grimbaldeston, MA., Piliponsky, AM., Williams, CM. \& Tsai, M. (2005). Mast cells as "tunable" effector and immunoregulatory cells: recent advances. Annu Rev Immunol 23:749-786.

García-de-Alba, C., Becerril, C., Ruiz, V., González, Y., Reyes, S., García-Alvarez, J., Selman, M. \& Pardo, A. (2010). Expression of matrix metalloproteases by fibrocytes: possible role in migration and homing. Am J Respir Crit Care Med. 182(9):1144-52.

Gibbs, DF., Warner, RL., Weiss, SJ., Johnson, KJ. \& Varani, J. (1999). Characterization of matrix metalloproteinases produced by rat alveolar macrophages. Am J Respir Cell Mol. 20: 1136-1144.

Godfraind, C., Louahed, J., Faulkner, H., Vink, A., Warnier, G., Grencis, R. \& Renauld, JC. (1998). Intraepithelial infiltration by mast cells with both connective tissue-type and mucosal-type characteristics in gut, trachea, and kidneys of IL-9 transgenic mice. J Immunol. 160(8):3989-96.

Goerdt, S. \& Orfanos, CE. (1999). Other functions, other genes: alternative activation of antigenpresenting cells. Immunity 10: 137-142.

Gordon, S. \& Taylor, PR. (2005). Monocyte and macrophage heterogeneity. Nature Rev Immunol. 5:953-964.

Gordon, S. (2003). Alternative activation of macrophages. Nat. Rev. Immunol. 3:23-35.

Grgic, I., Duffield, JS. \& Humphreys, BD. (2011). The origin of interstitial myofibroblasts in chronic kidney disease. Pediatr Nephrol. [Epub ahead of print]

Gruber, BL., Marchese, MJ. \& Kew, RR. (1994). Transforming growth factor-beta 1 mediates mast cell chemotaxis. J Immunol. 152: 5860-5867.

Gurtner, GC., Werner, S., Barrandon, Y. \& Longaker, MT. (2008). Wound repair and regeneration. Nature. 453(7193):314-21.

Hang, L., Frendéus, B., Godaly, G. \& Svanborg, C. (2000). Interleukin-8 receptor knockout mice have subepithelial neutrophil entrapment and renal scarring following acute pyelonephritis. J Infect Dis. 182(6):1738-48.

Hashimoto, N., Phan, SH., Imaizumi, K., Matsuo, M., Nakashima, H., Kawabe, T., Shimokata, K. \& Hasegawa, Y. (2010). Endothelial-mesenchymal transition in bleomycin-induced pulmonary fibrosis. Am J Respir Cell Mol Biol. 43(2):161-72.

He, C., Imai, M., Song, H., Quigg, RJ. \& Tomlinson, S. (2005). Complement inhibitors targeted to the proximal tubule prevent injury in experimental nephritic syndrome and demonstrate a key role for C5b-9. J Immunol. 174: 5750-5757. 
Hellberg, C., Ostman, A. \& Heldin, CH. (2010). PDGF and vessel maturation. Recent Results Cancer Res. 180:103-14.

Heller, F., Lindenmeyer, MT., Cohen, CD., Brandt, U., Draganovici, D., Fischereder, M., Kretzler, M., Anders, HJ., Sitter, T., Mosberger, I., Kerjaschki, D., Regele, H., Schlöndorff, D. \& Segerer, S. (2007). The contribution of B cells to renal interstitial inflammation. Am J Pathol. 170(2):457-68.

Herbert, DR., Hölscher, C., Mohrs, M., Arendse, B., Schwegmann, A., Radwanska, M., Leeto, M., Kirsch, R., Hall, P., Mossmann, H., Claussen, B., Förster, I. \& Brombacher, F. (2004). Alternative macrophage activation is essential for survival during schistosomiasis and downmodulates $\mathrm{T}$ helper 1 responses and immunopathology. Immunity. 20(5):623-35.

Hiromura, K., Kurosawa, M., Yano, S. \& Naruse, T. (1998). Tubulointerstitial mast cell infiltration in glomerulonephritis. Am J Kidney Dis. 32:593-599.

Hochberg, D., Johnson, CW., Chen, J., Cohen, D., Stern, J., Vaughan, ED Jr., Poppas, D. \& Felsen, D. (2000). Interstitial fibrosis of unilateral ureteral obstruction is exacerbated in kidneys of mice lacking the gene for inducible nitric oxide synthase. Lab Invest. 80(11):1721-8.

Holdsworth, SR. \& Summers, SA. (2008). Role of mast cells in progressive renal diseases. J Am Soc Nephrol. 19(12):2254-61.

Horton, JK., Davies, M., Topley, N., Thomas, D. \& Williams, JD. (1990). Activation of the inflammatory response of neutrophils by Tamm-Horsfall glycoprotein. Kidney Int. 37(2):717-26.

Huang, XR., Chen, WY., Truong, LD. \& Lan, HY. (2003). Chymase is upregulated in diabetic nephropathy: implications for an alternative pathway of angiotensin II-mediated diabetic renal and vascular disease. J Am Soc Nephrol. 14:1738-1747.

Humphreys, BD., Lin, SL., Kobayashi, A., Hudson, TE., Nowlin, BT., Bonventre, JV., Valerius, MT., McMahon, AP. \& Duffield, JS. (2010). Fate tracing reveals the pericyte and not epithelial origin of myofibroblasts in kidney fibrosis. Am J Pathol. 176(1):85-97.

Ichino, M., Kusaka, M., Kuroyanagi, Y., Mori, T., Morooka, M., Sasaki, H., Shiroki, R., Shishido, S., Kurahashi, H. \& Hoshinaga, K. (2010). Urinary neutrophil-gelatinase associated lipocalin is a potential noninvasive marker for renal scarring in patients with vesicoureteral reflux. J Urol. 183(5):2001-7.

Isaka, Y., Tsujie, M., Ando, Y., Nakamura, H., Kaneda, Y., Imai, E. \& Hori, M. (2000). Transforming growth factor-beta 1 antisense oligodeoxynucleotides block interstitial fibrosis in unilateral ureteral obstruction. Kidney Int. 58(5):1885-92.

Ishidoya, S., Morrissey, J., McCracken, R., Reyes, A. \& Klahr, S. (1995). Angiotensin II receptor antagonist ameliorates renal tubulointerstitial fibrosis caused by unilateral ureteral obstruction. Kidney Int. 47:1285-1294.

Iwano, M., Plieth, D., Danoff, TM, Xue, C., Okada, H. \& Neilson, EG. (2002). Evidence that fibroblasts derive from epithelium during tissue fibrosis. J Clin Invest. 110(3):341-50.

Jutel, M., Watanabe, T., Akdis, M., Blaser, K. \& Akdis, CA. (2002). Immune regulation by histamine. Curr Opin Immunol 14: 735-740

Kaissling, B., Hegyi, I., Loffing, J. \& Le Hir, M. (1996). Morphology of interstitial cells in the healthy kidney. Anat Embryol (Berl). 193(4):303-18.

Kalluri, R. \& Weinberg, RA. (2009). The basics of epithelial-mesenchymal transition. J Clin Invest. 119(6):1420-8.

Kaneto, H., Morrissey, J. \& Klahr, S. (1993). Increased expression of TGF-beta 1 mRNA in the obstructed kidney of rats with unilateral ureteral ligation. Kidney Int. 44: 313-321 
Kang, SJ., You, A. \& Kwak, MK. (2011). Suppression of Nrf2 signaling by angiotensin II in murine renal epithelial cells. Arch Pharm Res. 34(5):829-36.

Kellner, D., Chen, J., Richardson, I., Seshan, SV., El Chaar, M., Vaughan, ED Jr., Poppas, D. \& Felsen, D. (2006). Angiotensin receptor blockade decreases fibrosis and fibroblast expression in a rat model of unilateral ureteral obstruction. J Urol. 176:806-812.

Ketteler, M., Noble, NA. \& Border, WA. (1994). Increased expression of transforming growth factor-beta in renal disease. Curr Opin Nephrol Hypertens. 3(4):446-52.

Kim, H., Oda, T., López-Guisa, J., Wing, D., Edwards, DR., Soloway, PD. \& Eddy, AA. (2001). TIMP-1 deficiency does not attenuate interstitial fibrosis in obstructive nephropathy. J Am Soc Nephrol. 12(4):736-48.

Kim, SM., Jang, HR., Lee, YJ., Lee, JE., Huh, WS., Kim, DJ., Oh, HY. \& Kim, YG. (2011). Urinary angiotensinogen levels reflect the severity of renal histopathology in patients with chronic kidney disease. Clin Nephrol. 76(2):117-23.

Kisseleva, T., Uchinami, H., Feirt, N., Quintana-Bustamante, O., Segovia, JC., Schwabe, RF. \& Brenner, DA. (2006). Bone marrow-derived fibrocytes participate in pathogenesis of liver fibrosis. J Hepatol. 45(3):429-38.

Kitagawa, K., Wada, T., Furuichi, K., Hashimoto, H., Ishiwata, Y., Asano, M., Takeya, M., Kuziel, WA., Matsushima, K., Mukaida, N. \& Yokoyama, H. (2004). Blockade of CCR2 ameliorates progressive fibrosis in kidney. Am J Pathol. 165:237-246.

Kitamoto, K., Machida, Y., Uchida, J., Izumi, Y., Shiota, M., Nakao, T., Iwao, H., Yukimura, T., Nakatani, T. \& Miura, K. (2009). Effects of liposome clodronate on renal leukocyte populations and renal fibrosis in murine obstructive nephropathy. $J$ Pharmacol Sci. 111:285-292.

Kitamura, Y. (1989). Heterogeneity of mast cells and phenotypic change between subpopulations. Annu Rev Immunol. 7: 59-76

Kitching, AR. \& Holdsworth, SR. (2011). The emergence of TH17 cells as effectors of renal injury. J Am Soc Nephrol. 22(2):235-8.

Kitching, AR., Turner, AL., Wilson, GR., Semple, T., Odobasic, D., Timoshanko, JR., O'Sullivan, KM., Tipping, PG., Takeda, K., Akira, S. \& Holdsworth, SR. (2005). IL12 p40 and IL-18 in crescentic glomerulonephritis: IL-12p40 is the key Th1-defining cytokine chain, whereas IL-18 promotes local inflammation and leukocyte recruitment. J Am Soc Nephrol. 16(7):2023-33.

Koesters, R., Kaissling, B., Lehir, M., Picard, N., Theilig, F., Gebhardt, R., Glick, AB., Hähnel, B., Hosser, H., Gröne, HJ. \& Kriz, W. (2010). Tubular overexpression of transforming growth factor-beta1 induces autophagy and fibrosis but not mesenchymal transition of renal epithelial cells. Am J Pathol. 177(2):632-43.

Koni, PA., Joshi, SK., Temann, UA., Olson, D., Burkly, L. \& Flavell, RA. (2001). Conditional vascular adhesion molecule 1 deletion in mice; Impaired lymphocyte migration to bone marrow. J. Exp. Med. 193: 741-754.

Krausgruber, T., Blazek, K., Smallie, T., Alzabin, S., Lockstone, H., Sahgal, N., Hussell, T., Feldmann, M. \& Udalova, IA. (2011). IRF5 promotes inflammatory macrophage polarization and TH1-TH17 responses. Nat Immunol. 12(3):231-8.

Kuroiwa, T., Schlimgen, R., Illei, GG., McInnes, IB. \& Boumpas, DT. (2000). Distinct T cell/renal tubular epithelial cell interactions define differential chemokine production: implications for tubulointerstitial injury in chronic glomerulonephritides. J Immunol. 164(6):3323-9. 
Kushiyama, T., Oda, T., Yamada, M., Higashi, K., Yamamoto, K., Sakurai, Y., Miura, S. \& Kumagai, H. (2010). Alteration in the Phenotype Macrophages in the Repair of Renal Interstitial Fibrosis in Mice. Nephrology (Carlton). 16(5):522-35.

Kuwana, M., Okazaki, Y., Kodama, H., Izumi, K., Yasuoka, H., Ogawa, Y., Kawakami, Y. \& Ikeda, Y. (2003). Human circulating CD14+ monocytes as a source of progenitors that exhibit mesenchymal cell differentiation. J Leukoc Biol. 74(5):833-45.

Langenkamp, A., Messi, M., Lanzavecchia, A. \& Sallusto, F. (2000). Kinetics of dendritic cell activation: impact on priming of TH1, TH2 and nonpolarized T cells. Nat Immunol. 1(4):311-6.

Lesher, AM. \& Song, WC. (2010). Complement and its regulatory proteins in kidney diseases. Nephrology (Carlton). 15(7):663-75.

Lewis, EJ., Hunsicker, LG., Bain, RP. \& Rohde, RD. (1993). The effect of angiotensinconverting-enzyme inhibition on diabetic nephropathy. The Collaborative Study Group. N Engl J Med. 329(20):1456-62.

Li, P., Garcia, GE., Xia, Y., Wu, W., Gersch, C., Park, PW., Truong, L., Wilson, CB., Johnson, R. \& Feng, L. (2005). Blocking of monocyte chemoattractant protein-1 during tubulointerstitial nephritis resulted in delayed neutrophil clearance. Am J Pathol. 167(3):637-49.

Li, Z., Chung, AC., Zhou, L., Huang, XR., Liu, F., Fu, P., Fan, JM., Szalai, AJ. \& Lan, HY. (2011). C-reactive protein promotes acute renal inflammation and fibrosis in unilateral ureteral obstructive nephropathy in mice. Lab Invest. 91(6):837-51.

Limbourg, FP., Takeshita, K., Radtke, F., Bronson, RT., Chin, MT. \& Liao, JK. (2005). Essential role of endothelial Notch 1 in angiogenesis. Circulation. 111: 1826-1832.

Lin, SL., Kisseleva, T., Brenner, DA. \& Duffield, JS. (2008). Pericytes and perivascular fibroblasts are the primary source of collagen-producing cells in obstructive fibrosis of the kidney. Am J Pathol. 173(6):1617-27.

Liu Y. (2010). New insights into epithelial-mesenchymal transition in kidney fibrosis. J Am Soc Nephrol. 21(2):212-22.

Liu, L., Rich, BE., Inobe, J., Chen, W. \& Weiner, HL. (1998). Induction of Th2 cell differentiation in the primary immune response: dendritic cells isolated from adherent cell culture treated with IL-10 prime naive CD4+ T cells to secrete IL-4. Int Immunol. 10(8):1017-26.

Lu, LF., Lind, EF., Gondek, DC., Bennett, KA., Gleeson, MW., Pino-Lagos, K., Scott, ZA., Coyle, AJ., Reed, JL., Van Snick, J., Strom, TB., Zheng, XX. \& Noelle, RJ. (2006). Mast cells are essential intermediaries in regulatory T-cell tolerance. Nature. 442(7106):997-1002.

Lutz, J., Yao, Y., Song, E., Antus, B., Hamar, P., Liu, S. \& Heemann, U. (2005). Inhibition of matrix metalloproteinases during chronic allograft nephropathy in rats. Transplantation. 79: 655-661.

Machida, Y., Kitamoto, K., Izumi, Y., Shiota, M., Uchida, J., Kira, Y., Nakatani, T., Miura, K. (2010). Renal fibrosis in murine obstructive nephropathy is attenuated by depletion of monocyte lineage, not dendritic cells. J Pharmacol Sci. 114(4):464-73.

Mallamaci, F., Ruggenenti, P., Perna, A., Leonardis, D., Tripepi, R., Tripepi, G., Remuzzi, G. \& Zoccali C. (2011). ACE inhibition is renoprotective among obese patients with proteinuria. J Am Soc Nephrol. 22(6):1122-8.

Maloney, CG., Kutchera, WA., Albertine, KH., McIntyre, TM., Prescott, SM. \& Zimmerman, GA. (1998). Inflammatory agonists induce cyclooxygenase type 2 expression by human neutrophils. J Immunol. 160(3):1402-10. 
Mantovani, A., Sica, A., Sozzani, S., Allavena, P., Vecchi, A. \& Locati, M. (2004). The chemokine system in diverse forms of macrophage activation and polarization. Trends Immunol. 25(12):677-86.

Mantovani, A., Sica, A., Sozzani, S., Allavena, P., Vecchi, A. \& Locati, M. (2004). The chemokine system in diverse forms of macrophage activation and polarization. Trends Immunol. 25(12):677-86.

Matsuzaki, K. \& Okazaki, K. (2006). Transforming growth factor-beta during carcinogenesis: the shift from epithelial to mesenchymal signaling. J Gastroenterol. 41(4):295-303.

McCurdy, JD., Lin, TJ. \& Marshall, JS. (2001). Toll-like receptor 4-mediated activation of murine mast cells. J Leukoc Biol. 70: 977-984

McDonald, B., Pittman, K., Menezes, GB., Hirota, SA., Slaba, I., Waterhouse, CC., Beck, PL., Muruve, DA., Kubes, P. (2010). Intravascular danger signals guide neutrophils to sites of sterile inflammation. Science. 330(6002):362-6.

Meng, H., Marchese, MJ., Garlick, JA., Jelaska, A., Korn, JH., Gailit, J., Clark, RA. \& Gruber, BL. (1995). Mast cells induce T-cell adhesion to human fibroblasts by regulating intercellular adhesion molecule-1 and vascular cell adhesion molecule-1 expression. J Invest Dermatol 105: 789-796

Misseri, R., Meldrum, DR., Dinarello, CA., Dagher, P., Hile, KL., Rink, RC. \& Meldrum, KK. (2005). TNF-alpha mediates obstruction-induced renal tubular cell apoptosis and proapoptotic signaling. Am J Physiol Renal Physiol. 288:F406-F411.

Miyajima, A., Chen, J., Lawrence, C., Ledbetter, S., Soslow, RA., Stern, J., Jha, S., Pigato, J., Lemer, ML., Poppas, DP., Vaughan, ED. \& Felsen, D. (2000). Antibody to transforming growth factor-beta ameliorates tubular apoptosis in unilateral ureteral obstruction. Kidney Int. 58(6):2301-13.

Miyazawa, S., Hotta, O., Doi, N., Natori, Y., Nishikawa, K. \& Natori, Y. (2004). Role of mast cells in the development of renal fibrosis: use of mast cell-deficient rats. Kidney Int. 65(6):2228-37.

Mori, L., Bellini, A., Stacey, MA., Schmidt, M. \& Mattoli, S. (2005). Fibrocytes contribute to the myofibroblast population in wounded skin and originate from the bone marrow. Exp Cell Res. 304(1):81-90.

Morrissey, JJ., Ishidoya, S., McCracken, R. \& Klahr, S. (1996). Nitric oxide generation ameliorates the tubulointerstitial fibrosis of obstructive nephropathy. J Am Soc Nephrol. 7(10):2202-12.

Mosser, DM. \& Edwards, JP. (2008). Exploring the full spectrum of macrophage activation. Nat Rev Immunol. 8: 958-969.

Mu, W., Ouyang, X., Agarwal, A., Zhang, L., Long, DA., Cruz, PE., Roncal, CA., Glushakova, OY., Chiodo, VA., Atkinson, MA., Hauswirth, WW., Flotte, TR., Rodriguez-Iturbe, B. \& Johnson, RJ. (2005). IL-10 suppresses chemokines, inflammation, and fibrosis in a model of chronic renal disease. J Am Soc Nephrol. 16(12):3651-60.

Muller, DN., Shagdarsuren, E., Park, JK., Dechend, R., Mervaala, E., Hampich, F., Fiebeler, A., Ju, X., Finckenberg, P., Theuer, J., Viedt, C., Kreuzer, J., Heidecke, H., Haller, H., Zenke, M. \& Luft, FC. (2002). Immunosuppressive treatment protects against angiotensin II-induced renal damage. Am J Pathol. 161(5):1679-93.

Muller, WA. (2009). Mechanisms of transendothelial migration of leukocytes. Circ Res. 105: 223-230. 
Musial, A., \& Eissa, NT. (2001). Inducible nitric-oxide synthase is regulated by the proteasome degradation pathway. J Biol Chem. 276:24268-24273.

Nakae, S., Suto, H., Berry, GJ. \& Galli, SJ. (2007). Mast cell-derived TNF can promote Th17 celldependent neutrophil recruitment in ovalbumin-challenged OTII mice. Blood 109: 3640-3648

Ng, YY., Huang, TP., Yang, WC., Chen, ZP., Yang, AH., Mu, W., Nikolic-Paterson, DJ., Atkins, RC. \& Lan, HY. (1998). Tubular epithelial-myofibroblast transdifferentiation in progressive tubulointerstitial fibrosis in 5/6 nephrectomized rats. Kidney Int. 54(3):864-76.

Niedermeier, M., Reich, B., Rodriguez Gomez, M., Denzel, A., Schmidbauer, K., Göbel, N., Talke, Y., Schweda, F. \& Mack, M. (2009). CD4+ T cells control the differentiation of Gr1+ monocytes into fibrocytes. Proc Natl Acad Sci U S A. 106(42):17892-7.

Nishida, M., Fujinaka, H., Matsusaka, T., Price, J., Kon, V., Fogo, AB., Davidson, JM., Linton, MF., Fazio, S., Homma, T., Yoshida, H. \& Ichikawa, I. (2002). Absence of angiotensin II type 1 receptor in bone marrow-derived cells is detrimental in the evolution of renal fibrosis. J Clin Invest. 110:1859-1868.

Nishida, M., Okumura, Y., Ozawa, S., Shiraishi, I., Itoi, T. \& Hamaoka, K. (2007). MMP-2 inhibition reduces renal macrophage infiltration with increased fibrosis in UUO. Biochem Biophys Res Commun. 354(1):133-9.

Ostendorf, T., Eitner, F. \& Floege, J. (2011). The PDGF family in renal fibrosis. Pediatr Nephrol. [Epub ahead of print]

Ouyang, X., Le, TH., Roncal, C., Gersch, C., Herrera-Acosta, J., Rodriguez-Iturbe, B., Coffman, TM., Johnson, RJ. \& Mu, W. (2005). Th1 inflammatory response with altered expression of profibrotic and vasoactive mediators in AT1A and AT1B double-knockout mice. Am J Physiol Renal Physiol. 289(4):F902-10.

Ozes, ON., Mayo, LD., Gustin, JA., Pfeffer, SR., Pfeffer, LM. \& Donner, DB. (1999). NFkappaB activation by tumour necrosis factor requires the Akt serinethreonine kinase. Nature. 401:82-85.

Pavone-Macaluso, M. (1960). Tissue mast cells in renal diseases. Acta Pathol Microbiol Scand 50:337-346.

Payne, V. \& Kam, PC. (2004). Mast cell tryptase: a review of its physiology and clinical significance. Anaesthesia 59:695-703.

Peng, C. (2003). The TGF-beta superfamily and its roles in the human ovary and placenta. $J$ Obstet Gynaecol Can. 25(10):834-44.

Peters, H., Noble, NA. \& Border, WA. (1997). Transforming growth factor-beta in human glomerular injury. Curr Opin Nephrol Hypertens. 6(4):389-93.

Pohlers, D., Brenmoehl, J., Löffler, I., Müller, CK., Leipner, C., Schultze-Mosgau, S., Stallmach, A., Kinne, RW., Wolf, G.. (2009). TGF-beta and fibrosis in different organs - molecular pathway imprints. Biochim Biophys Acta. 1792(8):746-56.

Prodeus, AP., Zhou, X., Maurer, M., Galli, SJ. \& Carroll, MC. (1997). Impaired mast celldependent natural immunity in complement C3-deficient mice. Nature 390: 172-175

Raissian, Y., Nasr, SH., Larsen, CP., Colvin, RB., Smyrk, TC., Takahashi, N., Bhalodia, A., Sohani, AR., Zhang, L., Chari, S., Sethi, S., Fidler, ME. \& Cornell, LD. (2011). Diagnosis of IgG4-related tubulointerstitial nephritis. Am Soc Nephrol. 22(7):1343-52.

Rampoldi, L., Scolari, F., Amoroso, A., Ghiggeri, G. \& Devuyst, O. (2011). The rediscovery of uromodulin (Tamm-Horsfall protein): from tubulointerstitial nephropathy to chronic kidney disease. Kidney Int. 80(4):338-47. 
Ravetch, JV. \& Bolland, S. (2001). IgG Fc receptors. Annu Rev Immunol. 19:275-290.

Ren, Z., Liang, W., Chen, C., Yang, H., Singhal, PC. \& Ding, G. (2011). Angiotensin II induces nephrin dephosphorylation and podocyte injury: Role of caveolin-1. Cell Signal. [Epub ahead of print]

Ricardo, SD., van Goor, H. \& Eddy, AA. (2008). Macrophage diversity in renal injury and repair. J Clin Invest. 118(11):3522-30.

Ronco, P. \& Chatziantoniou, C. (2008). Matrix metalloproteinases and matrix receptors in progression and reversal of kidney disease: therapeutic perspectives. Kidney Int. 74: 873-878.

Rüster, C. \& Wolf, G. (2011). Angiotensin II as a morphogenic cytokine stimulating renal fibrogenesis. J Am Soc Nephrol. 22(7):1189-99.

Saeki, T., Saito, A., Yamazaki, H., Emura, I., Imai, N., Ueno, M., Nishi, S., Miyamura, S. \& Gejyo, F. (2007). Tubulointerstitial nephritis associated with IgG4-related systemic disease. Clin Exp Nephrol. 11(2):168-73.

Sawyer, DW., Donowitz, GR. \& Mandell, GL. (1989). Polymorphonuclear neutrophils: an effective antimicrobial force. Rev Infect Dis. 11 Suppl 7:S1532-44.

Schlaeger, TM., Bartunkova, S., Lawitts, JA., Teichmann, G., Risau, W., Deutsch, U. \& Sato, TN. (1997). Uniform vascular-endothelial-cell-specific gene expression in both embryonic and adult transgenic mice. Proc Natl Acad Sci U S A. 94(7):3058-63.

Schmidt, M., Sun, G., Stacey, MA., Mori, L. \& Mattoli, S. (2003) Identification of circulating fibrocytes as precursors of bronchial myofibroblasts in asthma. J Immunol. 171(1):380-9.

Scudamore, CL., Jepson, MA., Hirst, BH. \& Miller, HR. (1998). The rat mucosal mast cell chymase, RMCP-II, alters epithelial cell monolayer permeability in association with altered distribution of the tight junction proteins ZO-1 and occludin. Eur J Cell Biol. 75: 321-330.

Seifert, RA., Alpers, CE. \& Bowen-Pope, DF. (1998) Expression of platelet-derived growth factor and its receptors in the developing and adult mouse kidney. Kidney Int. 54(3):731-46.

Sharma, AK., Mauer, SM., Kim, Y. \& Michael, AF. (1995). Altered expression of matrix metalloproteinase-2, TIMP, and TIMP-2 in obstructive nephropathy. J Lab Clin Med. 125(6):754-61.

Siragy, HM. (2004). AT1 and AT2 receptor in the kidney: role in health and disease. Semin Nephrol. 24(2):93-100.

Song, E., Ouyang, N., Horbelt, M., Antus, B., Wang, M. \& Exton, MS. (2000). Influence of alternatively and classically activated macrophages on fibrogenic activities of human fibroblasts. Cell Immunol. 204: 19-28.

Sorokin, L. (2010). The impact of the extracellular matrix on inflammation. Nat Rev Immunol. 10: 712-723.

Steinmetz, OM., Sadaghiani, S., Panzer, U., Krebs, C., Meyer-Schwesinger, C., Streichert, T., Fehr, S., Hamming, I., van Goor, H., Stahl, RA. \& Wenzel, U. (2007). Antihypertensive therapy induces compartment-specific chemokine expression and a Th1 immune response in the clipped kidney of Goldblatt hypertensive rats. Am J Physiol Renal Physiol. 292(2):F876-87.

Strutz, F. \& Neilson, EG. (1994). The role of lymphocytes in the progression of interstitial disease. Kidney Int. Suppl. 45:S106-10. 37. 
Supajatura, V., Ushio, H., Nakao, A., Akira, S., Okumura, K., Ra, C. \& Ogawa, H. (2002). Differential responses of mast cell Toll-like receptors 2 and 4 in allergy and innate immunity. J Clin Invest. 109: 1351-1359

Suzuki, Y., Ruiz-Ortega, M., Lorenzo, O., Ruperez, M., Esteban, V. \& Egido J. (2003). Inflammation and angiotensin II. Int J Biochem Cell Biol. 35(6):881-900.

Swaminathan, S. \& Griffin, MD. (2008). First responders: understanding monocyte-lineage traffic in the acutely injured kidney. Kidney In.t 74: 1509-1511.

Tacke, F. \& Randolph, GJ. (2006). Migratory fate and differentiation of blood monocyte subsets. Immunobiology 211:609-618.

Tang, WW., Ulich, TR., Lacey, DL., Hill, DC., Qi, M., Kaufman, SA, Van, GY., Tarpley, JE. \& Yee, JS. (1996). Platelet derived growth factor-BB induces renal tubulointerstitial myofibroblastmformation and tubulointerstitial fibrosis. Am J Pathol. 148:1169-1180.

Tapmeier, TT., Fearn, A., Brown, K., Chowdhury, P., Sacks, SH., Sheerin, NS. \& Wong, W. (2010). Pivotal role of CD4+ T cells in renal fibrosis following ureteric obstruction. Kidney Int. 78(4):351-62.

Thiery, JP. \& Sleeman, JP. (2006). Complex networks orchestrate epithelial-mesenchymal transitions. Nat Rev Mol Cell Biol. 7(2):131-42.

Topley, N., Steadman, R. \& Williams JD. (2005). Neutrophil activation and renal scarring. Kidney Int. 67(6):2504

Trojanowska, M. (2008). Role of PDGF in fibrotic diseases and systemic sclerosis. Rheumatology (Oxford). 47 Suppl 5:v2-4.

Tsuda, Y., Takahashi, H., Kobayashi, M., Hanafusa, T., Herndon, DN. \& Suzuki, F. (2004). Three different neutrophil subsets exhibited in mice with different susceptibilities to infection by methicillin-resistant Staphylococcus aureus. Immunity. 21(2):215-26.

Tucci, M., Ciavarella, S., Strippoli, S., Dammacco, F. \& Silvestris, F. (2009). Oversecretion of cytokines and chemokines in lupus nephritis is regulated by intraparenchymal dendritic cells: a review. Ann N Y Acad Sci. 1173:449-57.

Tucci, M., Quatraro, C., Lombardi, L., Pellegrino, C., Dammacco, F. \& Silvestris, F. (2008). Glomerular accumulation of plasmacytoid dendritic cells in active lupus nephritis: role of interleukin-18. Arthritis Rheum. 58(1):251-62.

Turner, JE., Paust, HJ., Steinmetz, OM. \& Panzer, U. (2010). The Th17 immune response in renal inflammation. Kidney Int. 77(12):1070-5.

Verkade, MA., van Druningen, CJ., Vaessen, LM., Hesselink, DA., Weimar, W. \& Betjes, MG. (2007). Functional impairment of monocyte-derived dendritic cells in patients with severe chronic kidney disease. Nephrol Dial Transplant. 22(1):128-38.

Vielhauer, V., Anders, HJ., Mack, M., Cihak, J., Strutz, F., Stangassinger, M., Luckow, B., Gröne, HJ. \& Schlöndorff, D. (2001). Obstructive nephropathy in the mouse: progressive fibrosis correlates with tubulointerstitial chemokine expression and accumulation of CC chemokine receptor 2- and 5-positive leukocytes. J Am Soc Nephrol. 12(6):1173-87.

Wada, T., Furuichi, K., Sakai, N., Iwata, Y., Kitagawa, K., Ishida, Y., Kondo, T., Hashimoto, H., Ishiwata, Y., Mukaida, N., Tomosugi, N., Matsushima, K., Egashira, K. \& Yokoyama, H. (2004). Gene therapy via blockade of monocyte chemoattractant protein-1 for renal fibrosis. J Am Soc Nephrol. 15: 940-948.

Wajant, H., Pfizenmaier, K. \& Scheurich, P. (2003). Tumor necrosis factor signaling. Cell Death Differ. 10: 45-65. 
Weidner, S., Carl, M., Riess, R. \& Rupprecht, HD. (2004). Histologic analysis of renal leukocyte infiltration in antineutrophil cytoplasmic antibody-associated vasculitis: importance of monocyte and neutrophil infiltration in tissue damage. Arthritis Rheum. 50(11):3651-7.

Winkler, EA., Bell, RD. \& Zlokovic, BV. (2010). Pericyte-specific expression of PDGF beta receptor in mouse models with normal and deficient PDGF beta receptor signaling. Mol Neurodegener. 5:32.

Wu, K., Zhou, T., Sun, G., Wang, W., Zhang, Y., Zhang, Y., Hao, L. \& Chen, N. (2006). Valsartan inhibited the accumulation of dendritic cells in rat fibrotic renal tissue. Cell Mol Immunol. 3(3):213-20.

Wynn, TA. (2004). Fibrotic disease and the T(H)1/T(H)2 paradigm. Nat Rev Immunol. 4: 583-594. Xu, H., He, X., Sun, J., Shi, D., Zhu, Y. \& Zhang, X. (2009). The expression of B-cell activating factor belonging to tumor necrosis factor superfamily (BAFF) significantly correlated with C4D in kidney allograft rejection. Transplant Proc. 41(1):112-6.

Yamagishi, H., Yokoo, T., Imasawa, T., Shen, JS., Hisada, Y., Eto, Y., Kawamura, T. \& Hosoya, T. (2001). Genetically modified bone marrow-derived vehicle cells site specifically deliver an anti-inflammatory cytokine to inflamed interstitium of obstructive nephropathy. J Immunol. 166:609-616.

Yang, J. \& Liu, Y. (2001). Dissection of key events in tubular epithelial to myofibroblast transition and its implications in renal interstitial fibrosis. Am J Pathol. 159(4):1465-75.

Yang, L., Scott, PG., Giuffre, J., Shankowsky, HA., Ghahary, A. \& Tredget EE. (2002). Peripheral blood fibrocytes from burn patients: identification and quantification of fibrocytes in adherent cells cultured from peripheral blood mononuclear cells. Lab Invest. 82(9):1183-92.

Zeisberg, EM., Potenta, S., Xie, L., Zeisberg, M. \& Kalluri, R. (2007b). Discovery of endothelial to mesenchymal transition as a source for carcinomaassociated fibroblasts. Cancer Res. 67:10123-10128,

Zeisberg, EM., Potenta, SE., Sugimoto, H., Zeisberg, M. \& Kalluri, R. (2008). Fibroblasts in kidney fibrosis emerge via endothelial-to-mesenchymal transition. J Am Soc Nephrol. 19(12):2282-7.

Zeisberg, EM., Tarnavski, O., Zeisberg, M., Dorfman, AL., McMullen, JR., Gustafsson, E., Chandraker, A., Yuan, X., Pu, WT., Roberts, AB., Neilson, EG., Sayegh, MH., Izumo, S. \& Kalluri, R. (2007a). Endothelial-to-mesenchymal transition contributes to cardiac fibrosis. Nat Med. 13(8):952-61.

Zeisberg, M., Khurana, M., Rao, VH., Cosgrove, D., Rougier, JP., Werner, MC., Shield, CF., Werb, Z. \& Kalluri, R. (2006). Stage-specific action of matrix metalloproteinases influences progressive hereditary kidney disease. PLoS Med. 3(4):e100.

Zhang, JL., Sun, DJ., Hou, CM., Wei, YL., Li, XY., Yu, ZY., Feng, JN., Shen, BF., Li, Y. \& Xiao, H. (2010). CD3 mAb treatment ameliorated the severity of the cGVHD-induced lupus nephritis in mice by up-regulation of Foxp3+ regulatory $\mathrm{T}$ cells in the target tissue: kidney. Transpl Immunol. 24(1):17-25.

Zhao, Y., Glesne, D. \& Huberman, E. (2003). A human peripheral blood monocytederived subset acts as pluripotent stem cells. Proc Natl Acad Sci USA. 100:2426-2431.

Zhou, T., Li, X., Zou, J., Cai, M., Sun, G., Zhang, Y., Zhao, Y., Zhang, M., Zhang, Y. \& Chen, N. (2009). Effects of DC-SIGN expression on renal tubulointerstitial fibrosis in nephritis. Front Biosci. 14:3814-24. 


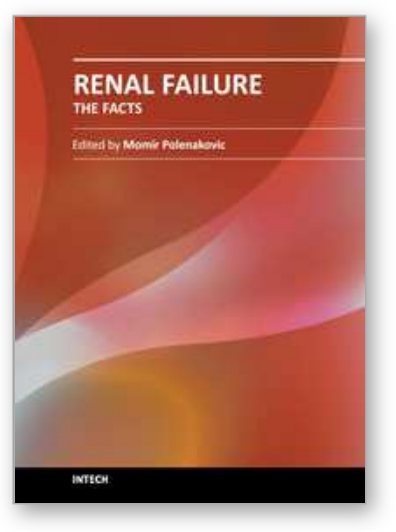

\author{
Renal Failure - The Facts \\ Edited by Dr. Momir Polenakovic
}

ISBN 978-953-51-0630-2

Hard cover, 270 pages

Publisher InTech

Published online 23, May, 2012

Published in print edition May, 2012

The book "Renal Failure - The Facts" consists of some facts about diagnosis, etiopathogenis and treatment of acute and chronic renal failure. Acute, as well as chronic renal failure is great medical problems and their treatment is a burden for the budget of each government. The purpose of the chapters is to present some important issues of diagnosis and causes of AKI, as well as caused by snakes and arthropods, after cardiac surgery, as well as some therapeutic achievements in AKI. Well presented are the psychological condition in patients on haemodialysis, as well as the treatment of diabetic uremics. The book is aimed at clinicians with a special interest in nephrology, but it should also prove to be a valuable resource for any generalists who encounter a nephrological problems in their day-to-day practice.

\title{
How to reference
}

In order to correctly reference this scholarly work, feel free to copy and paste the following:

Leonora Himer, Erna Sziksz, Tivadar Tulassay and Ádám Vannay (2012). Immunological and Molecular Mechanisms Leading to Fibrosis: Origin of Renal Myofibroblasts, Renal Failure - The Facts, Dr. Momir Polenakovic (Ed.), ISBN: 978-953-51-0630-2, InTech, Available from: http://www.intechopen.com/books/renalfailure-the-facts/pathomechanism-of-renal-fibrosis

\section{INTECH}

open science | open minds

\section{InTech Europe}

University Campus STeP Ri Slavka Krautzeka 83/A 51000 Rijeka, Croatia Phone: +385 (51) 770447 Fax: +385 (51) 686166 www.intechopen.com

\author{
InTech China \\ Unit 405, Office Block, Hotel Equatorial Shanghai \\ No.65, Yan An Road (West), Shanghai, 200040, China \\ 中国上海市延安西路65号上海国际贵都大饭店办公楼405单元 \\ Phone: +86-21-62489820 \\ Fax: +86-21-62489821
}


(C) 2012 The Author(s). Licensee IntechOpen. This is an open access article distributed under the terms of the Creative Commons Attribution 3.0 License, which permits unrestricted use, distribution, and reproduction in any medium, provided the original work is properly cited. 